
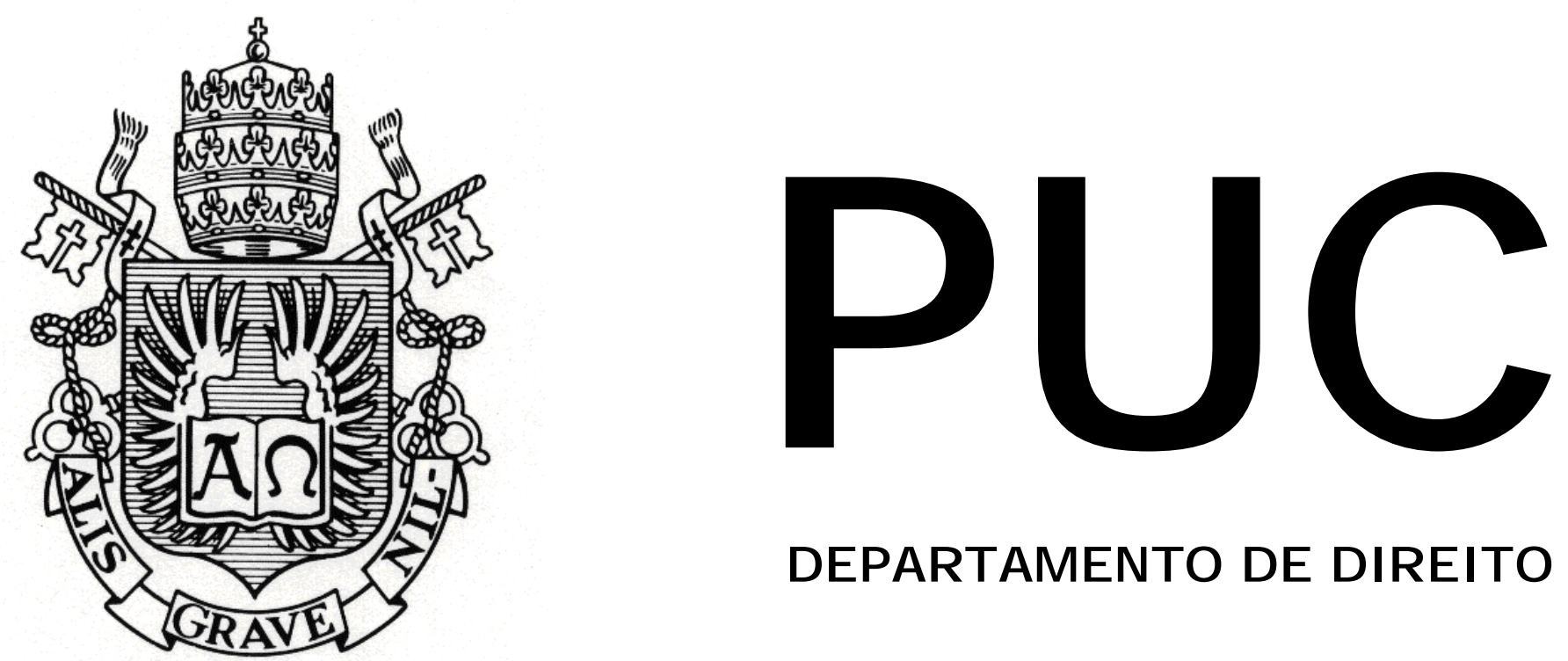

DEPARTAMENTO DE DIREITO

\title{
OPERAÇÕES DE SECURITIZAÇÃO NO MERCADO IMOBILIÁRIO
}

por

CARLA SABACK DAU

ORIENTADOR: PAULO EDUARDO PENNA

2013.1

PONTIFÍCIA UNIVERSIDADE CATÓLICA DO RIO DE JANEIRO

RUA MARQUÊS DE SÃO VICENTE, 225 - CEP 22453-900

RIO DE JANEIRO - BRASIL 


\title{
OPERAÇÕES DE SECURITIZAÇÃO NO MERCADO IMOBILIÁRIO
}

\author{
por \\ CARLA SABACK DAU
}

Monografia apresentada ao

Departamento de Direito da Pontifícia Universidade Católica do Rio de Janeiro (PUC-Rio) para a obtenção do Título de Bacharel em Direito.

Orientador: Paulo Eduardo Penna 


\section{Dedicatória}

Ao meu avô paterno, Albert Dau (in memoriam), de quem herdei a vocação jurídica, pelo exemplo e constante inspiração. 


\section{Agradecimentos}

Primeiramente, agradeço aos meus pais, Vera e Miguel, desde sempre meus maiores e melhores amigos, pelo apoio incondicional. Devo a eles todas as minhas conquistas, pois sem o suporte dado por eles, certamente não chegaria onde estou hoje. Obrigada por sempre terem sido os meus maiores incentivadores.

Ao meu irmão, Rodrigo, o maior presente que meus pais poderiam ter me dado, pela amizade e cumplicidade. Agradeço pela compreensão e, principalmente, pelo companheirismo.

Às minhas irmãs por escolha, Mariana Mattos, Julia Mafra e Isadora Tostes, por mais uma vez estarem presentes e compartilhando comigo outra importante etapa da minha vida.

Às melhores companheiras de faculdade que tive a oportunidade de conhecer ao longo desses cinco anos, que certamente seguirão comigo, pois sem essas amizades esta etapa da minha vida não teria sido tão feliz e inesquecível, especialmente: Alessandra Bentes, Ariane Baars, Fernanda Vieira, Joana Mello, Jordana Fontes, Mariana Ricci e Renata Zeitune.

Ao Luiz Felipe Gonçalves Cordeiro, pela parceria de sempre, não só acadêmica como também profissional.

À Glória Brasil, Dionísio Taunay e Mariano Morales, com os quais tive o privilégio e a honra de iniciar minha carreira e com quem prendi o real significado de trabalho em equipe. Agradeço por terem sido muito mais do que chefes, mas minha família.

Ao meu orientador, Paulo Penna, por toda atenção e dedicação dispensadas durante a elaboração da presente monografia. 
Por fim, mas não menos importante, ao meu amigo, chefe e mentor, Alexandre Rangel, em quem me espelho, por, de certa forma, ser o responsável pela escolha do tema do presente trabalho, pois sem ele jamais teria conhecido e me interessado pelas operações estruturadas e pela securitização. Obrigada por ter apostado em mim desde o início e confiado no meu trabalho. 


\section{Resumo}

A presente monografia pretende estudar o crescente fenômeno da securitização de recebíveis, especificamente no que tange ao mercado imobiliário, analisando a estrutura das emissões de Certificados de Recebíveis Imobiliários. Inicialmente será analisada a regulação vigente referente à matéria e o contexto histórico em que a securitização foi introduzida no ordenamento brasileiro. Em seguida será verificada a finalidade prática dos diversos tipos de operações de securitização. Por fim, analisar-se-á mais detalhadamente cada uma das etapas e agentes envolvidos na emissão dos Certificados de Recebíveis Imobiliários.

Palavras-Chave: Operações Estruturadas - Mercado Imobiliário Securitização de Créditos Imobiliários - Certificados de Recebíveis Imobiliários - Cédulas de Crédito Imobiliário - Fundo de Investimento Imobiliário. 


\section{Lista de Abreviações}

BCB - Banco Central do Brasil

CCB - Cédula de Crédito Bancário

CCI - Cédula de Crédito Imobiliário

CDA - Certificado de Depósito Agropecuário

CDCA - Certificado de Direitos Creditórios do Agronegócio

CETIP - Cetip S.A. - Mercados Organizados

CMN - Conselho Monetário Nacional

CPR - Cédula de Produto Rural

CRA - Certificado de Recebíveis do Agronegócio

CRI - Certificado de Recebível Imobiliário

CVM - Comissão de Valores Mobiliários

FII - Fundo de Investimento Imobiliário

LCA - Letra de Crédito do Agronegócio

RGI - Registro Geral de Imóveis

SPE - Sociedade de Propósito Específico 


\section{Sumário}

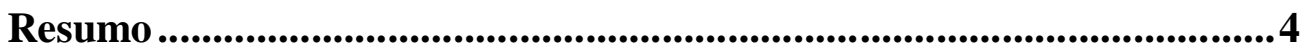

Introdução.....................................................................................................9

Capítulo I - Securitização ..................................................................................11

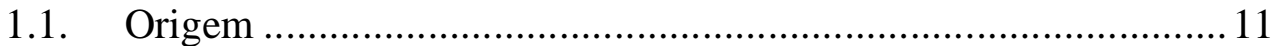

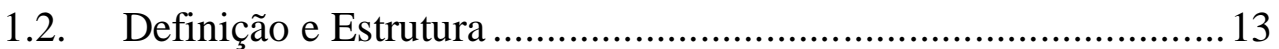

1.3. Finalidades e Vantagens da Operação de Securitização.................. 15

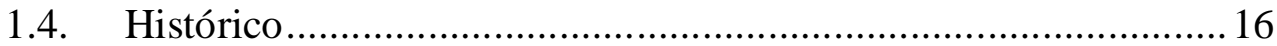

Capítulo II - Tipos de Securitização................................................................. 18

2.1. Regime Legal e Sistema Regulatório no Brasil ............................. 18

2.2. Securitização de Exportação ...........................................................20

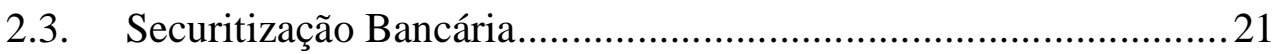

2.4. Securitização de Agronegócio.........................................................22

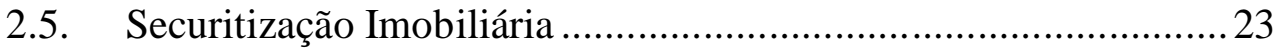

Capítulo III - Finalidades da Securitização no Mercado Imobiliário ..25

3.1. Antecipação de Receita na Incorporação Imobiliária ..........................25

3.2. Desmobilização do Ativo Fixo ……………………………………....2 27

Capítulo IV - Estrutura das Emissões de CRI..............................................30

4.1. Certificados de Recebíveis Imobiliários ..............................................31

4.2. Lastro Inicial das Operações e o Conceito de Crédito Imobiliário .....32

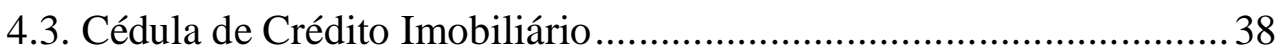

4.4. Tipos de Emissão de CCI.................................................................. 40

4.4.1. Sale and Leaseback ................................................................ 41

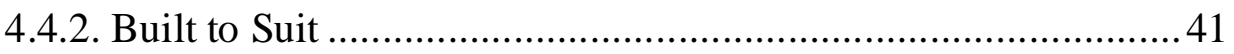

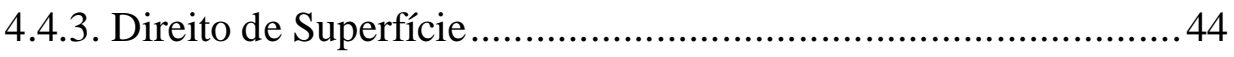

4.5. Securitização das CCI e Emissão dos CRI ........................................ 45

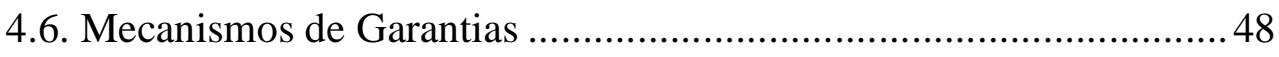

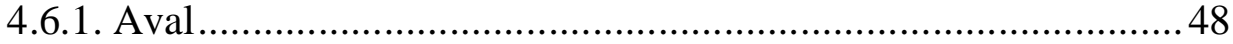

4.6.2. Hipoteca e Alienação Fiduciária ..............................................50

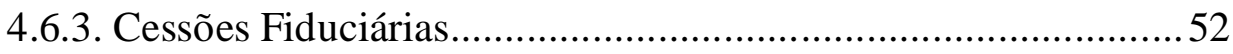


4.6.4. Patrimônio Separado...........................................................55

4.7. Participantes das Operações ................................................... 57

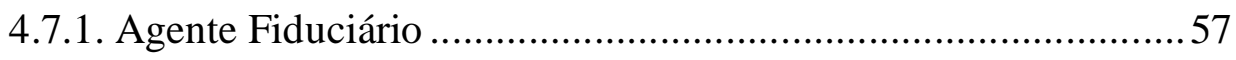

4.7.2. Coordenador Líder ou Underwriter ........................................59

4.7.3. Agências de Rating ........................................................62 62

4.8. Tipos de Oferta Pública de Distribuição...................................... 63

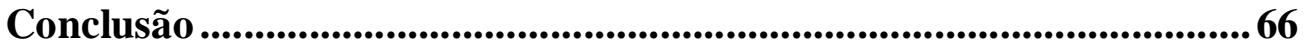

Referências Bibliográficas..........................................................................68 


\section{Introdução}

A presente monografia pretende estudar o crescente fenômeno da securitização de recebíveis, especificamente no que tange ao mercado imobiliário, analisando a estrutura das emissões de Certificados de Recebíveis Imobiliários.

Inicialmente, é importante destacar a dificuldade de se escrever sobre o tema, tendo em vista que o assunto ainda é pouquíssimo abordado pela doutrina brasileira, quase não havendo materiais acadêmicos e doutrinários. Além disso, considerando ser a securitização um instrumento financeiro relativamente recente em nosso ordenamento, são poucas as manifestações no âmbito judicial e administrativo que envolvam questões relacionadas ao tema da presente monografia.

A vivência profissional na área de operações estruturadas e securitizações imobiliárias e as dificuldades enfrentadas no dia-a-dia, decorrentes desta insuficiência de estudos e abordagens, foram os principais fatores envolvidos na escolha deste tema.

O presente trabalho se limitará a analisar a estrutura das emissões de CRI no mercado de capitais, destacando as possíveis estruturas de constituição do crédito imobiliário, os principais agentes envolvidos e as garantias mais comumente prestadas no âmbito das operações. Neste contexto, serão abordadas algumas discussões relacionadas à estrutura destas operações, ressaltando-se, porém, que tais discussões não compreendem o foco desta monografia.

Sendo assim, a estruturação dos capítulos foi feita da seguinte forma:

No primeiro capítulo, procurou-se, inicialmente, definir e conceituar o instituto da securitização, analisando sua estrutura básica, suas principais finalidades e sua origem histórica. 
Já no segundo capítulo, busca-se uma abordagem prática, analisando-se o regime jurídico ao qual a securitização está sujeita e descrevendo cada tipo específico de securitização atualmente regulamentado no ordenamento brasileiro.

O terceiro capítulo demonstra como o instituto da securitização, na qualidade de financiamento, é utilizado no mercado imobiliário, avaliando as suas finalidades e benefícios.

Por fim, o quarto e último capítulo, representa o foco do presente trabalho, analisando de forma detalhada cada uma das etapas de uma operação de securitização imobiliária e indicando (i) as diversas estruturas para constituição do lastro imobiliário; (ii) as possíveis garantias a serem concedidas no âmbito da operação; e (iii) os principais agentes envolvidos na estruturação. 


\section{Capítulo I - Securitização}

\subsection{Origem}

Em razão do seu intenso dinamismo, os mercados financeiro e de capitais estão em constante reinvenção, passando por momentos de euforia e depressão, liquidez e repressão, regulamentação e desregulamentação.

A globalização muito tem contribuído para a integração dos mercados mundiais, fazendo com que seu ambiente fique cada vez mais instável, o que intensifica ainda mais a velocidade das mudanças de padrão e de comportamento dos agentes econômicos que lutam para se adequar às novas condições dos mercados nos quais participam.

Como resultado desse constante fluxo de mudanças, os agentes econômicos estão a todo tempo buscando novos instrumentos financeiros que atendam às suas demandas e necessidades dentro das novas realidades econômicas dos mercados, objetivando sempre eficiência e proteção de recursos.

Neste contexto, uma situação verificada com bastante frequência em qualquer mercado é a necessidade constante de recursos financeiros por parte da atividade empresária para a realização de investimentos que permitam sua sobrevivência. Tais recursos podem ser provenientes de capital próprio ou de terceiros.

O capital próprio, como o nome já indica, tem sua origem no aporte de capital feito pelos sócios ou acionistas ou na capitalização dos lucros, como resultado produzido pela própria sociedade empresária. O capital próprio, contabilmente, integra o conceito de patrimônio líquido.

Distintamente, o capital de terceiros implica na obtenção de recursos através do mercado financeiro, por meio de empréstimos bancários, ou, no 
caso de sociedades anônimas, através do mercado de capitais, por meio de emissão de valores mobiliários.

A estrutura de capital de uma sociedade é extremamente importante, pois deve buscar um equilíbrio entre os recursos provenientes do capital próprio e os recursos provenientes da captação junto a terceiros, para evitar uma alta alavancagem financeira da sociedade. Pode-se afirmar que muitas vezes é interessante para uma sociedade obter recursos através da contração de dívidas. No entanto, essa forma de captação deve ser avaliada de forma bastante cuidadosa, uma vez que a utilização de capital de terceiros implica em uma série de pontos negativos.

O primeiro deles é o surgimento de uma contraprestação no passivo da sociedade. Em outras palavras, a utilização de capital de terceiros gera para a sociedade uma obrigação de devolver o montante utilizado, acrescido de juros remuneratórios, ficando tal obrigação registrada no balanço patrimonial como uma exigibilidade. É importante destacar que, em geral, a obrigação de restituir os recursos obtidos através de empréstimo perdura ainda que a sociedade não apure resultados positivos.

O segundo ponto negativo, decorre diretamente do primeiro e diz respeito ao aumento do grau de endividamento da sociedade, o que impacta diretamente a sua saúde financeira. Além disso, quando estivermos tratando de empréstimo bancário, a concessão do crédito implica também na diminuição do limite de crédito da sociedade com outras instituições.

Por fim, também vale mencionar que o uso de capital de terceiros poderá elevará o custo do produto ou do serviço a ser alienado ou prestado pela sociedade, em razão do custo de captação dos recursos, enquanto o real objetivo de toda e qualquer empresa é diminuí-lo, buscando torná-lo mais competitivo no mercado. 
A pergunta que se faz, então, é: por que não utilizar sempre o capital próprio? A resposta é bastante simples. Nem sempre a sociedade e seus sócios ou acionistas dispõem de capital suficiente para seu propósito.

Diante deste quadro o desafio que se coloca, nas palavras de Fernando Schwarz Gaggini, é "encontrar meios de obtenção de crédito, de financiamento, oferecendo maiores garantias e desvinculando o risco da empresa, de forma a, consequentemente, se obter recursos a um custo final menor" 1 .

Como já mencionado, para solucionar este e tantos outros desafios que surgem no dia a dia da atividade empresarial, os mercados estão em constante evolução, buscando inovações financeiras que atendam às demandas e necessidades empresariais.

É neste contexto que surgem as operações de securitização de recebíveis, uma ferramenta financeira cada vez mais utilizada como uma alternativa mais vantajosa para captação de recursos.

\subsection{Definição e Estrutura}

De acordo com Uinie Caminha ${ }^{2}$ o termo securitização possui uma definição em sentido amplo, significando desintermediação financeira; e outra em sentido estrito, significando um tipo de instrumento de desintermediação.

Securitização, em sentido estrito, significa qualquer operação financeira que tenha por objetivo emitir títulos ou valores mobiliários lastreados em direitos de crédito.

Nas palavras de Luiz Ferreira Xavier Borges:

\footnotetext{
${ }^{1}$ GAGGINI, Fernando Schwarz. Securitização de Recebíveis. São Paulo: Livraria e Editora Universitária de Direito, 2003, p. 18.

${ }^{2}$ CAMINHA, Uinie. Securitização. $2^{\mathrm{a}}$ ed.. São Paulo: Saraiva, 2007, p. 37.
} 
[...] securitização é o termo utilizado para identificar aquelas operações em que o valor mobiliário emitido, de alguma forma, está lastreado ou vinculado a um direito de crédito, também denominado de direito creditório ou simplesmente recebível. Uma receita, que é uma expectativa de resultado, torna-se um recebível quando surge uma relação jurídica que lhe dê respaldo, originada de um contrato ou de um título de crédito ${ }^{3}$.

Portanto, para que uma empresa possa se valer de uma operação de securitização, é indispensável que ela seja titular de direitos de crédito ou recebíveis, pois será com base neles que toda a operação será estruturada.

A securitização inicia-se com a chamada segregação do risco, ou seja, com o isolamento dos recebíveis. A sociedade titular dos direitos de crédito, aqui chamada de sociedade originadora, transfere os recebíveis para uma segunda sociedade, através de uma cessão de direitos de crédito ${ }^{4}$.

Essa segunda sociedade pode se apresentar de três formas: (i) ser constituída com o único e exclusivo objetivo de receber aqueles direitos de crédito, sendo nesses casos designada como Sociedade de Propósito Específico (SPE); (ii) ser uma companhia securitizadora; ou ainda (iii) ser um fundo de investimento. Para os fins desse capítulo, iremos trabalhar com a ideia de constituição de uma SPE, por se tratar do veículo mais simples e que congrega os principais conceitos tratados neste trabalho.

Sendo assim, após a transferência e segregação dos créditos, a SPE emite valores mobiliários com lastro nos recebíveis cedidos. Através da emissão dos valores mobiliários no mercado, a SPE capta recursos na medida em que os investidores adquirem tais títulos, e com eles paga a sociedade originadora pela transferência dos créditos. O fluxograma apresentado abaixo consolida resumidamente a estrutura supracitada:

\footnotetext{
${ }^{3}$ BOGES, Luiz Ferreira Xavier. Securitização como parte da segregação de risco empresarial. Revista de Direito Bancário e do Mercado de Capitais. Vol. 10, p. 257.

4 Deve-se mencionar que existem as chamadas securitizações sem segregação de risco, caracterizadas pela não utilização de uma segunda sociedade. Neste tipo de operação os valores mobiliários são emitidos pela própria sociedade originadora dos direitos de crédito ou dos recebíveis. Tais direitos são vinculados aos valores mobiliários através de um vínculo jurídico obrigacional (custódia) ou real (penhor ou caução). Essa é a tendência utilizada no caso das companhias concessionárias de serviços estatais, que têm menos flexibilidade para criar subsidiárias.
} 


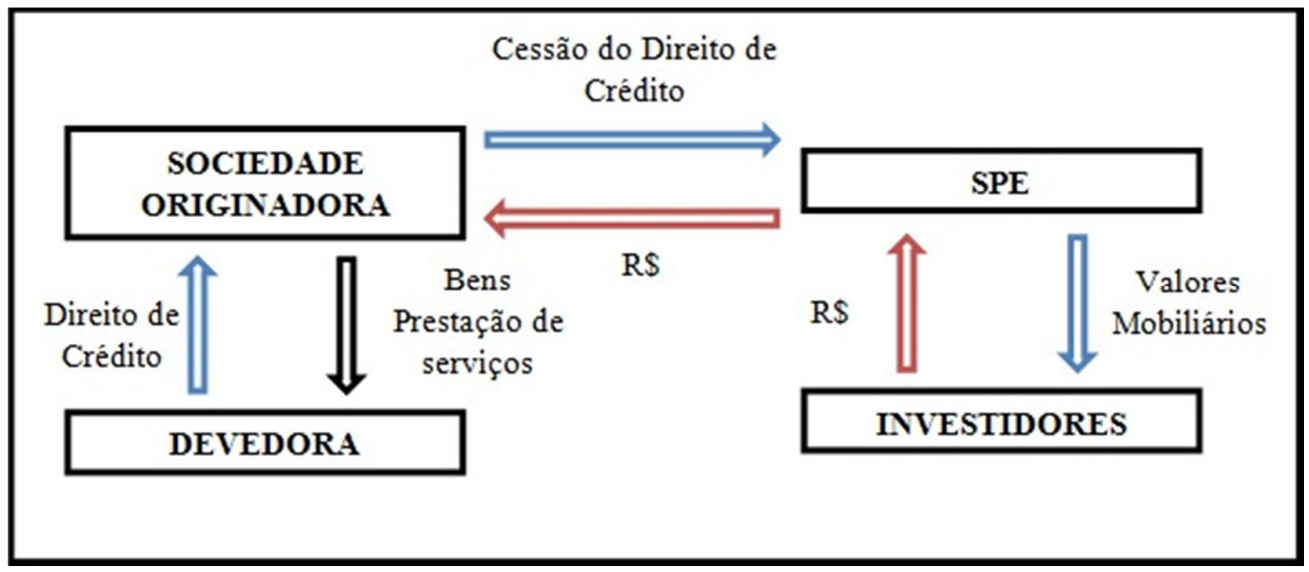

Estrutura básica de uma operação de securitização de recebíveis.

\subsection{Finalidades e Vantagens da Operação de Securitização}

Essa estrutura de captação de recursos traz vantagens não apenas para o investidor que irá adquirir o título ou valor mobiliário no mercado de capitais, mas também para a sociedade originadora.

Como resultado final, a sociedade originadora acaba por antecipar o recebimento dos recursos com um desconto, sem prejudicar sua saúde financeira, pois como não se trata de um financiamento propriamente dito, não há aumento do seu grau de endividamento, tampouco diminuição do seu limite de crédito. Essa antecipação de receitas futuras acaba por gerar um fluxo de caixa, possibilitando o financiamento e investimento em novos projetos.

Além disso, ao transferir o crédito para os investidores que subscrevem os valores mobiliários emitidos pela SPE, a sociedade originadora acaba também por diluir o risco de sua carteira de recebíveis, pois também transfere o risco de não pagamento de tais créditos.

Por fim, outra vantagem dessa estrutura é a captação de recursos por um custo muito inferior caso a sociedade originadora optasse pela realização de um empréstimo no mercado bancário, ou caso ela própria realizasse as emissões dos valores mobiliários no mercado de capitais. Portanto, trata-se de um mecanismo que permite o acesso ao mercado de 
capitais sem necessidade de abertura de capital por parte da sociedade originadora.

Do ponto de vista do investidor, o mecanismo de segregação dos ativos torna o valor mobiliário um investimento de baixo risco, pois, sendo a emissora a SPE e não a sociedade originadora, o único risco envolvendo os títulos emitidos será o do próprio crédito que o lastreia. Isso somente é possível na medida em que a SPE não possui nenhum outro ativo ou passivo que não aqueles relacionados à operação. Portanto, a SPE tem capacidade de captar os recursos a um custo muito menor do que o da sociedade originadora.

Em outras palavras, o fato de os créditos que lastreiam a emissão não mais pertencerem à sociedade originadora, mas sim à SPE, significa para o investidor não estar exposto aos riscos da originadora. Todos os riscos envolvendo a atividade econômica desempenhada pela sociedade originadora, incluindo todo o seu passivo, estão totalmente desvinculados do valor mobiliário negociado no mercado, pois ela não é mais a titular daqueles créditos.

Essa estrutura cria uma alternativa, inclusive para sociedades com dificuldades financeiras, que poderão se capitalizar utilizando apenas seus direitos de crédito, já que a segregação dos ativos impedirá que os riscos do seu negócio afetem os valores mobiliários emitidos pela SPE.

\subsection{Histórico}

As primeiras operações de securitização ocorreram nos anos 70 nos Estados Unidos. Surgiram como uma alternativa ao financiamento imobiliário, em razão da escassez de crédito deste mercado e a crescente demanda por recursos. 
O termo securitização acaba não guardando qualquer relação técnica com seu significado prático, pois tem sua origem na tradução livre do termo securitization, muito utilizado no mercado financeiro norte-americano para indicar operações de transformação de ativos em securities, termo que muito se assemelha ao nosso conceito de valor mobiliário.

Dessa forma, a securitização nada mais é do que uma prática financeira utilizada para transformar direitos de crédito, também chamados de recebíveis, em valores mobiliários.

No Brasil, a primeira operação de securitização ocorreu nos anos 90 e envolveu o Grupo Mesbla, antiga rede popular de lojas de departamento. A operação teve como sociedade originadora a Mesbla Lojas de Departamento S.A. ("Mesbla S.A."), que à época enfrentava fortes dificuldades financeiras em razão não apenas de erros em relação ao excesso de estoque de mercadorias e dívidas com bancos, como também do contexto histórico-econômico do governo Collor.

Essa pioneira experiência implicou na constituição da Mesbla Trust de Recebíveis de Cartões de Crédito S.A. ("Mesbla Trust"), sociedade de propósito específico para a qual foram transferidos os recebíveis decorrentes das vendas e prestações de serviços realizadas pela Mesbla S.A.

Foram, então, emitidas debêntures com garantia real, constituída através do penhor dos direitos creditórios anteriormente cedidos pela Mesbla S.A. à Mesbla Trust.

Essa operação possibilitou a captação de recursos pela Mesbla S.A., sem que os debenturistas tivessem que se expor ao risco da atividade econômica exercida pela sociedade originadora. 


\section{Capítulo II - Tipos de Securitização}

\subsection{Regime Legal e Sistema Regulatório no Brasil}

Em geral, a securitização ainda não possui regulação específica no ordenamento jurídico brasileiro, ao contrário do que acontece em alguns países do sistema romano-germânico, como Portugal, Itália, França e Argentina. Como se viu, por se tratar de uma ferramenta financeira que permite a antecipação de receitas futuras, tal instrumento pode ser aplicado em diversos setores, com base em diferentes tipos de ativos.

Atualmente verificam-se operações de securitização lastreadas em recebíveis de cartão de crédito, recebíveis imobiliários, hipotecas comerciais, empréstimos para compra de automóveis, equipamentos arrendados, franchise fees e até mesmo de direitos de propriedade intelectual ${ }^{5}$.

Por esse motivo, sua regulação no Brasil se desenvolveu de forma muito específica, sempre em observância aos ativos que lastreiam a securitização, não havendo uma regra básica aplicável a securitização de ativos em geral. Portanto, apenas alguns tipos de operações, como, por exemplo, securitizações de créditos bancários, imobiliários e de exportação, possuem tratamento normativo próprio. Nas hipóteses em que não há amparo normativo específico, aplicam-se as regras gerais de Direito Civil e Comercial.

É preciso ter em mente que os agentes envolvidos nessas operações buscam, acima de tudo, segurança nos mecanismos e instrumentos utilizados.

\footnotetext{
${ }^{5}$ Em 1997, o cantor David Bowie emitiu títulos (Bowie Bonds) lastreados nos créditos presentes e futuros decorrentes do pagamento de royalties de 25 álbuns (287 músicas). Os títulos foram adquiridos por US\$ 55 milhões de dólares pela Prudential Insurance Company of America. Essa operação é considerada a primeira operação de securitização de direitos de propriedade intelectual, que mais para frente também foi utilizada por artistas como Rod Stewart.
} 
Neste sentido, ensina Uinie Caminha:

[...] assim como os instrumentos de mobilização de riquezas têm por função primordial fazê-las circular pelo maior número de pessoas possível, a tutela jurídica torna-se essencial para que esses instrumentos, criados a partir de necessidades econômicas, se tornem plenamente eficazes e cumpram a função para o qual foram criados ${ }^{6}$.

Atualmente, a estrutura das operações se vale de diversos instrumentos jurídicos consagrados em nosso ordenamento, tais como contratos de compra e venda, contratos de locação, alienação fiduciária de bem imóvel e, principalmente aqueles relacionados à transferência, cessão e circulação de crédito. Por essa razão, são aplicadas as normas gerais de direito civil previstas na Lei $\mathrm{n}^{\circ} 10.406 / 2002$, bem como as normas relacionadas aos títulos de crédito.

Porém, estas normas nem sempre se demonstram adequadas e eficientes na prática, trazendo alguns pontos polêmicos ${ }^{7}$. Essa flexibilidade do tratamento jurídico da securitização faz com que muitos defendam que a falta de diretrizes pré-estabelecidas traz certo nível de incerteza às operações, se posicionando de forma favorável à edição de uma regulação própria para os diversos contratos celebrados no âmbito de uma operação de securitização.

Por outro lado, se levarmos em conta que a estrutura das operações de securitização envolve contratos e instrumentos jurídicos amplamente utilizados na prática e já enfrentados pelo judiciário, pode-se considerar que sua utilização, por já possuir certa previsibilidade, acaba conferindo segurança jurídica à operação.

\footnotetext{
${ }^{6}$ CAMINHA, Uinie. Securitização, p. 76 e 77.

${ }^{7}$ Podemos citar como exemplo a questão envolvendo a alienação fiduciária do imóvel. Em geral, as incorporadoras celebram com os terceiros adquirentes dos imóveis uma escritura de compra e venda com pacto adjeto de alienação fiduciária. Isso significa que, imediatamente após ter se tornado proprietário da unidade imobiliária, o terceiro adquirente transfere a propriedade fiduciariamente à incorporadora como mecanismo de garantia pelo pagamento do preço de aquisição. No âmbito da operação de securitização, como se verá adiante, é extremamente usual que a incorporadora aliene fiduciariamente em garantia o imóvel onde o empreendimento está sendo implementado, de forma a garantir as obrigações assumidas na operação de securitização. Nasce, portanto, um conflito. O mesmo bem é alienado fiduciariamente duas vezes, garantindo obrigações diversas.
} 


\subsection{Securitização de Exportação}

Foi em 1991, com a edição da Resolução CMN nº 1.834, de 26 de junho de 1991, regulamentada pela Circular do BCB $\mathrm{n}^{\circ} 1.979$, de 27 de junho de 1991 que as operações de securitização foram legalmente disciplinadas no Brasil, ainda que não houvesse expressa menção ao termo "securitização".

Atualmente, a securitização de exportações é disciplinada pela Circular do BCB $\mathrm{n}^{\circ}$ 3.027, de 22 de fevereiro de 2011, que institui e regulamenta, dentre outras operações de crédito externo, operações de crédito com vínculo a exportação. Em outras palavras, trata-se de operação de securitização com lastro em créditos oriundos da exportação de bens.

De forma resumida, a estrutura dessa operação conta com uma sociedade exportadora brasileira (sociedade originadora), credora de recebíveis provenientes de contratos de exportação e uma SPE constituída no exterior, responsável pela aquisição dos direitos creditórios e posterior emissão de valores mobiliários no mercado externo lastreados nos recebíveis adquiridos. Com os recursos captados através da subscrição dos valores mobiliários negociados no mercado, a SPE adquirirá os direitos creditórios de titularidade da sociedade originadora (exportadora), possibilitando assim, o adiantamento desses recebíveis. Confira-se o fluxograma a seguir: 


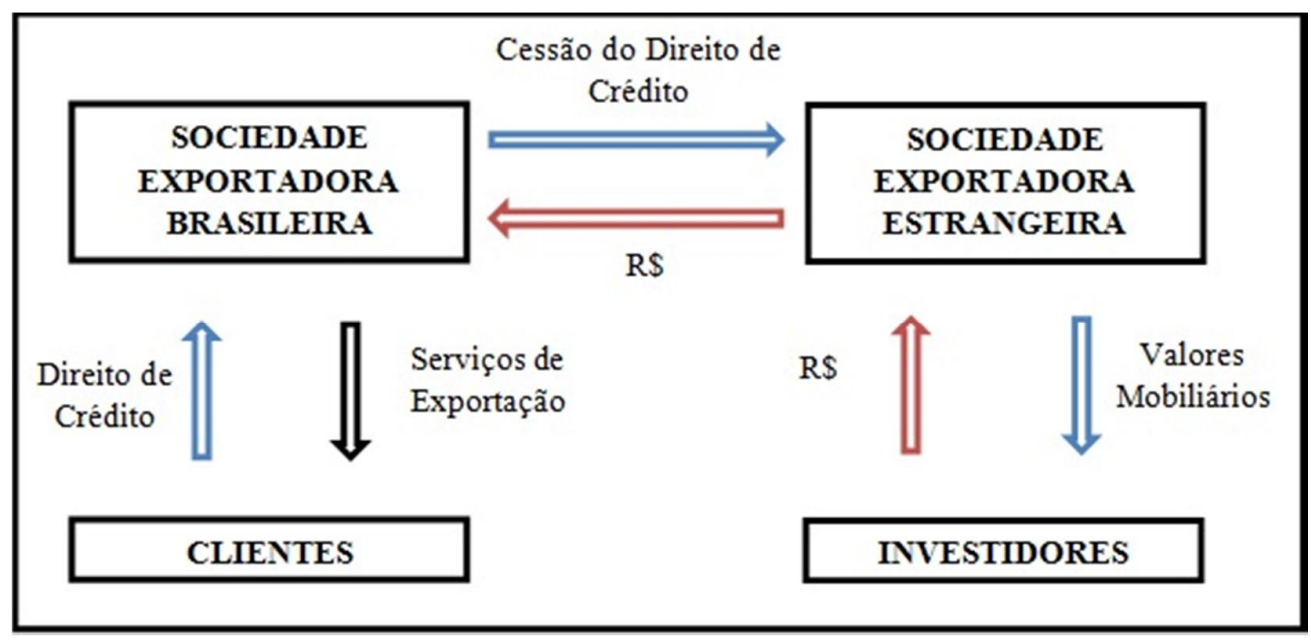

Estrutura de uma securitização de recebíveis de exportação.

\subsection{Securitização Bancária}

A securitização de créditos bancários se caracteriza pela cessão de recebíveis oriundos de operações financeiras, de titularidade de bancos múltiplos, bancos comerciais, bancos de investimento, sociedades de crédito, financiamento e investimento, sociedades de crédito imobiliário, sociedades de arrendamento mercantil, companhias hipotecárias, associações de poupança e empréstimo e da Caixa Econômica Federal, para companhias securitizadoras de créditos financeiros.

Essa modalidade de securitização somente foi autorizada no Brasil em 1998, com a edição da Resolução do CMN nº 2.493/1998, revogada pela Resolução no 2.686, de 26 de janeiro de 2001, normativo atualmente em vigor.

A securitização bancária utiliza a mesma estrutura apresentada nas operações de securitização já mencionadas no presente trabalho: as instituições financeiras transferem os recebíveis decorrentes de operações financeiras para uma SPE (neste caso, necessariamente uma companhia securitizadora de créditos financeiros), que, lastreada em tais créditos, emite títulos e valores mobiliários no mercado. Mediante a captação de recursos 
no mercado de capitais, a securitizadora adquire os créditos de titularidade das instituições financeiras.

A Resolução no 2.686/2000 dispõe que as companhias securitizadoras de créditos financeiros estão restritas a captar recursos no país apenas através da emissão de ações, debêntures não conversíveis (para distribuição pública) ou de debêntures não conversíveis subordinadas (para distribuição pública ou privada), sendo, no entanto, permitido captar investimentos no exterior, desde que observadas as normas vigentes.

Por fim, é importante mencionar que há uma preocupação mundial por parte dos bancos centrais e das agências reguladoras quanto aos mecanismos de securitização de créditos de instituições financeiras. Segundo Uinie Caminha, essa preocupação se fundamente em dois motivos:

[...] em primeiro lugar, porque a securitização pode ser considerada uma forma de elidir as exigências de adequação de capital imposta aos bancos e demais instituições financeiras; e, em segundo lugar, em razão de perderem parte de seu controle sobre os ativos de tais instituições e, com especialidade, sobre parte dos mecanismos de política monetária ${ }^{8}$.

\subsection{Securitização de Agronegócio}

Buscando disponibilizar uma nova opção de financiamento à produção agrícola, a Lei no 11.076 , de 30 de dezembro de 2004, criou novos títulos do agronegócio e instituiu a securitização de direitos creditórios do agronegócio.

De acordo com a definição prevista no artigo 40 do referido normativo, a securitização de direitos creditórios do agronegócio é a operação pela qual tais direitos são expressamente vinculados à emissão de uma série de títulos de crédito, mediante termo de securitização de direitos creditórios, emitido por uma companhia securitizadora de direitos

\footnotetext{
${ }^{8}$ CAMINHA, Uinie. Securitização, p. 158.
} 
creditórios do agronegócio. Através desse tipo de operação, as securitizadoras emitem Certificados de Recebíveis do Agronegócio (CRA), representativos de promessa de pagamento em dinheiro.

Portanto, a sociedade originadora, detentora de créditos do agronegócio, os cede para uma companhia securitizadora, que, lastreada nos créditos cedidos, emite no mercado os CRAs. A emissão de CRAs pode ter como lastro Cédulas de Produto Rural (CRPs), Certificados de Direitos Creditórios do Agronegócio (CDCAs), Letras de Crédito do Agronegócio (LCAs), dentre outros.

\subsection{Securitização Imobiliária}

Apesar de primeira operação de securitização ter ocorrido no Brasil no início dos anos 90, foi apenas no final da década, com a edição da Lei ${ }^{\circ}$ 9.514, de 20 de novembro de 1997, que a securitização passou a ter previsão legal e fazer parte do ordenamento jurídico brasileiro com o nome que hoje a conhecemos. A mencionada lei, que dispõe sobre o Sistema Financeiro Imobiliário, surgiu como uma solução ao déficit de recursos para o financiamento habitacional ao instituir a securitização de créditos imobiliários e criar as chamadas companhias securitizadoras de créditos imobiliários.

Nos termos do artigo $3^{\circ}$, as companhias securitizadoras de créditos imobiliários são caracterizadas como instituições não financeiras constituídas sob a forma de sociedade por ações, que têm por finalidade a aquisição e securitização de créditos imobiliários e a emissão e colocação, no mercado financeiro, de Certificados de Recebíveis Imobiliários (CRIs), podendo emitir outros títulos de crédito, realizar negócios e prestar serviços compatíveis com as suas atividades. 
Assim como ocorre nas operações de securitização bancária e de agronegócio, a legislação restringe quem poderá figurar como cessionário dos direitos de crédito.

O artigo $8^{\circ}$ da Lei $n^{\circ}$ 9.514/1997 define a securitização de créditos imobiliários como sendo a operação pela qual tais créditos são expressamente vinculados à emissão de uma série de títulos de crédito, mediante termo de securitização de créditos, lavrado por uma companhia securitizadora.

As sociedades titulares de créditos imobiliários, através de um contrato de cessão, cedem e transferem os créditos à companhia securitizadora, realizando a segregação do risco mencionada acima. Em seguida, a securitizadora de créditos imobiliários reúne os créditos recém adquiridos para, com lastro neles, emitir no mercado os CRIs. Como contraprestação à cessão dos créditos, a sociedade originadora será remunerada pela securitizadora com os recursos provenientes da integralização dos CRIs pelos investidores.

Podemos afirmar que o CRI é um dos produtos da securitização imobiliária, no entanto, não é o único.

Como mencionado, o termo securitização abarca qualquer operação que tenha por finalidade transformar ativos em títulos ou valores mobiliários, podendo, portanto, as operações serem estruturadas de diversas formas, sempre levando em conta as finalidades da sociedade originadora. 


\section{Capítulo III - Finalidades da Securitização no Mercado Imobiliário}

Além da obtenção das vantagens inerentes ao mecanismo da securitização, abordadas no Capítulo I, de forma geral podemos visualizar duas finalidades que fundamentam e justificam a constante utilização e o forte crescimento das operações de securitização no mercado imobiliário.

A primeira delas está relacionada à antecipação de receitas, ou seja, um mecanismo de financiamento que não onera o passivo das sociedades, resultando em uma melhora significativa dos índices econômicos e financeiros da sociedade. A segunda está relacionada à desmobilização do ativo fixo da sociedade, permitindo a liberação dos recursos que estavam até então parados. Passamos a analisar a estrutura das operações frequentemente utilizadas para essas duas finalidades.

\subsection{Antecipação de Receita na Incorporação Imobiliária}

A incorporação imobiliária, instituída pela Lei $\mathrm{n}^{\circ} 4.591$, de 16 de dezembro de 1964 e também regulada pela Lei no 10.931, de 02 de agosto de 2004, nas palavras do professor Melhim Chalhub, "é a atividade empresarial que se caracteriza pela produção e comercialização de imóveis em construção, integrantes de conjuntos imobiliários" ${ }^{9}$.

A alienação antecipada das unidades imobiliárias a terceiros adquirentes, ou seja, antes da conclusão das obras, se justifica na medida em que o incorporador captará os recursos necessários à consecução das obras por meio dos pagamentos efetuados pelos adquirentes.

Isso acontece porque, na maior parte dos casos, o incorporador não possui os recursos necessários para colocar em prática a construção do

\footnotetext{
${ }^{9}$ CHALHUB, Melhim Namen. Alienação Fiduciária, Incorporação Imobiliária e Mercado de Capitais. Estudos e Pareceres. Rio de Janeiro: Renovar, 2012, p. 241.
} 
empreendimento imobiliário, sendo apenas proprietário do terreno onde a construção será realizada.

No entanto, a prática do mercado envolve a celebração da compra e venda definitiva ou da promessa de compra e venda das unidades imobiliárias, na qual o incorporador se compromete a vender a unidade como coisa futura e entregá-la pronta e o promitente comprador se obriga a pagar o preço acordado, geralmente em parcelas de longo prazo.

O fato de a venda dos imóveis ocorrer a prazo acaba inviabilizando o projeto como um todo, pois o fundamento central da incorporação imobiliária acaba anulado, uma vez que os recursos ao invés de serem antecipados e recebidos de uma única vez, serão transferidos ao incorporador parceladamente. Porém, sem recursos o incorporador não tem condições de dar início à realização das obras.

É nesse ponto que a securitização ganha espaço, pois será por meio da captação junto a investidores no mercado de capitais, por meio da securitização dos direitos de créditos do incorporador junto aos terceiros adquirentes dos imóveis, que todo o projeto será financiado.

O incorporador, mediante a celebração de um contrato de cessão de crédito, transferirá para uma companhia securitizadora de créditos imobiliários os recebíveis oriundos dos contratos de compra e venda pactuados com os terceiros adquirentes das unidades imobiliárias.

A companhia securitizadora, por sua vez, com o do termo de securitização, vinculará os créditos de todos os contratos de compra e venda celebrados a um único título, qual seja, o certificado de recebíveis imobiliários, para, em sequencia, ofertá-lo aos investidores no mercado de capitais.

A securitizadora, na medida em que os certificados de recebíveis imobiliários forem subscritos pelos investidores, captará os recursos 
necessários para o pagamento da contraprestação pela aquisição dos créditos imobiliários, anteriormente de propriedade do incorporador.

Ao final da operação (i) o incorporador consegue adiantar o recebimento de todos os valores devidos pelos adquirentes, estando apto a iniciar as obras; (ii) o incorporador deixa de ser o credor dos terceiros adquirentes; (iii) os investidores assumem a posição de credores junto aos terceiros adquirentes; e (iv) os terceiros adquirentes permanecem obrigados a realizar o pagamento pela aquisição das unidades imobiliárias, com a única ressalva de que, a partir de então, o pagamento será feito diretamente aos investidores e não mais ao incorporador.

\subsection{Desmobilização do Ativo Fixo}

O conceito de ativo fixo ou ativo imobilizado é dado pela contabilidade e compreende todos os bens necessários e essenciais à realização da atividade fim de uma sociedade, como, por exemplo, automóveis, máquinas, imóveis etc. São bens que, pela sua importância, não serão vendidos a curto prazo pela sociedade ou são bens com baixa liquidez, ou seja, que não podem ser facilmente convertidos em dinheiro.

No entanto, muitas vezes os bens que compõem o ativo fixo de uma sociedade não estão diretamente relacionados à sua atividade central, sendo apenas um meio necessário para viabilizá-la.

Tomemos como exemplo uma fábrica produtora de latinhas de refrigerante. As máquinas que compõem o ativo imobilizado não podem ser vendidas, tendo em vista seu caráter essencial para realização da produção. Por outro lado, o imóvel onde a fábrica está instalada é necessário na medida em que, sem ele, não há fábrica e sem fábrica não há produção.

A questão que se coloca é que os recursos financeiros equivalentes ao valor do imóvel ficam travados no ativo imobilizado, já que em algum 
momento a sociedade utilizou tais recursos para adquirir a propriedade desse imóvel.

No entanto, se considerarmos que esses recursos, travados no ativo imobilizado, poderiam estar investidos ou sendo utilizados no desenvolvimento de novos projetos da empresa, percebemos que não há nenhuma necessidade de a sociedade ser a proprietária.

Mais uma vez a securitização aparece como uma solução para o impasse, porém nesse caso ela não será estruturada com a emissão de certificados de recebíveis imobiliários, mas com a emissão de quotas de um fundo de investimento imobiliário ${ }^{10}$, que apesar de possuir uma estrutura muito próxima, não é considerada como securitização propriamente dita

A sociedade que pretende levantar os recursos imobilizados no imóvel celebrará com um fundo de investimento imobiliário um contrato de compra e venda, transferindo a propriedade do imóvel ao fundo de investimento. A sociedade proprietária vendedora passará, assim, a ser credora do fundo de investimento adquirente.

No entanto, o fundo de investimento precisa, de alguma forma, obter recursos para efetuar o pagamento do preço do imóvel adquirido e por outro lado, a sociedade vendedora ainda necessita do imóvel para dar continuidade às suas atividades.

Sendo assim, logo após a celebração do contrato de compra e venda, a sociedade e o fundo celebram um contrato de locação, por meio do qual o fundo aluga à sociedade, antiga proprietária, o imóvel recém adquirido. Nesse momento, a sociedade que anteriormente era credora do fundo, em razão da celebração de compra e venda, se torna devedora do fundo, obrigando-se ao pagamento dos aluguéis.

${ }^{10}$ A securitização com fins de desmobilização do ativo também pode ser estruturada com a emissão de certificados de recebíveis imobiliários, mas para diversificar os exemplos e demonstrar a variedade de estruturações, neste trabalho iremos utilizar como exemplo a emissão de quotas de um fundo de investimento imobiliário. 
Lastreado nos recebíveis dos aluguéis o fundo de investimento emite suas quotas no mercado de capitais, que, na medida em que são subscritas pelos investidores, permitem ao fundo a captação dos recursos necessários ao pagamento do preço de aquisição do imóvel.

Os investidores serão remunerados na medida em que a sociedade (antiga proprietária) efetuar o pagamento mensal dos alugueis.

\section{Segundo Uinie Caminha:}

Os fundos de investimento imobiliário, mesmo não sendo expressamente considerados mecanismos de securitização, conceitualmente apresentam suas mesmas características, já que, como na securitização, segregam-se ativos específicos para posterior emissão de títulos neles lastreados ${ }^{11}$.

Esse tipo de operação cria uma espécie de vínculo entre o fundo adquirente e o antigo proprietário do imóvel, na medida em que o contrato de locação é celebrado por longo período, permitindo e assegurando ao fundo o retorno do seu investimento através do pagamento dos aluguéis e garantindo ao antigo proprietário o controle de suas operações, na medida em que permanecerá utilizando o imóvel. Além disso, possibilita ao antigo proprietário o levantamento de recursos de forma imediata, podendo alocar esse capital em novos projetos e no desenvolvimento do negócio.

\footnotetext{
${ }^{11}$ CAMINHA, Uinie. Securitização, p. 145.
} 


\section{Capítulo IV - Estrutura das Emissões de CRI}

Da mesma forma que o instrumento financeiro da securitização pode ser aplicado a diversos tipos de ativos, dando origem a diversos tipos de securitização, dentre eles a securitização imobiliária, está última também pode ser estruturada de diversas formas, conforme demonstrado no Capítulo anterior.

Podemos imaginar uma operação de emissão de quotas de um fundo de investimento imobiliário ou de um fundo de investimento em direitos creditórios, a emissão de valores mobiliários através de uma sociedade de propósito específico ou, ainda, a emissão de certificados de recebíveis imobiliários por meio de uma companhia securitizadora de créditos imobiliários.

Independentemente do título ou do valor mobiliário que será emitido e dos veículos utilizados na operação, todas possuem as mesmas características centrais e uma estrutura básica comum compreendida por cinco etapas.

A primeira delas compreende a constituição do crédito imobiliário, ou seja, trata-se da formação do lastro para a emissão dos valores mobiliários, pois, sem ser titular de direitos de crédito, a sociedade que pretende se financiar não poderá se valer da securitização.

A segunda fase abrange a emissão, pela própria sociedade originadora, de cédulas de crédito imobiliário, que nada mais são do que títulos de crédito representativos do crédito do qual a sociedade originadora é titular. Essa etapa também é de suma importância tendo em vista que a emissão das CCI permitirá a circulação do crédito.

A terceira etapa envolve a cessão e transferência das CCI ao veículo que será responsável pela emissão dos títulos ou valores mobiliários no 
mercado de capitais, seja ele uma SPE, um FII, FIDC ou uma companhia securitizadora.

A quarta e quinta etapas abrangem a securitização propriamente dita, representada pela emissão dos títulos ou valores mobiliários no mercado e a subscrição por parte dos investidores, fechando o ciclo da operação.

Para os fins do presente trabalho, levaremos em consideração apenas uma operação de securitização imobiliária estruturada através da emissão de certificado de recebíveis imobiliários com base na Lei $n^{\circ}$ 9.514/1997, analisando detalhadamente cada uma das etapas descritas e os instrumentos jurídicos utilizados para formalizar a operação.

\subsection{Certificados de Recebíveis Imobiliários}

Os certificados de recebíveis imobiliários são definidos pela Lei $\mathrm{n}^{\circ}$ 9.514/1997 como sendo títulos de crédito nominativos, de livre negociação, lastreados em créditos imobiliários e constituem promessa de pagamento em dinheiro. Em outras palavras, podemos dizer que os CRI nada mais são do que títulos oriundos do "empacotamento" ou "agrupamento" de diversos créditos imobiliários (geralmente representados por cédulas de crédito imobiliário).

Por força da Resolução do Conselho Monetário Nacional no 2.517, de 29 de junho de 1998, além de serem caracterizados como título de crédito, os CRIs são também considerados valores mobiliários para os fins do artigo $2^{\circ}$, inciso III, da Lei ${ }^{\circ}$ 6.385, de 07 de dezembro de 1976.

Nos termos do parágrafo único do artigo $6^{\circ}$ da Lei $\mathrm{n}^{\circ}$ 9.514/1997, os CRIs são de emissão exclusiva das companhias securitizadoras que o fazem através da celebração do termo de securitização de créditos. 


\subsection{Lastro Inicial das Operações e o Conceito de Crédito Imobiliário}

Para que uma sociedade possa se valer da securitização como fonte de financiamento, através da emissão de certificados de recebíveis imobiliários é necessário, antes de qualquer coisa, que esta sociedade seja titular de direitos de créditos imobiliários. Essa exigência tem fundamento da redação do artigo $6^{\circ}$ da Lei $n^{\circ} 9.514 / 1997$, que determina que o CRI deve ser lastreado em créditos imobiliários. No entanto, o conceito do que seja um crédito imobiliário não é claro.

Uma das discussões que se coloca é saber se somente são considerados créditos imobiliários aqueles créditos que têm sua origem ou algum tipo de vínculo com operações imobiliárias em geral (ex.: contrato de compra e venda, contrato de financiamento para aquisição de imóvel) ou são aqueles que, independentemente de sua origem e finalidade, são garantidos pela constituição de uma garantia real (ex.: hipoteca, alienação fiduciária).

A edição da Lei no 9.514/1997 e da Lei no $10.931 / 2004$ permitiu a ampliação das operações envolvendo créditos imobiliários, que até então estavam restritas à realização de operações de financiamento habitacional. Porém, nenhuma das duas normas se preocupou em definir e explicitar o que é o crédito imobiliário, utilizando o termo de forma bastante genérica.

Parte da controvérsia se fundamenta na redação do parágrafo $3^{\circ}$, do artigo 18 e do inciso II, do artigo 19, da Lei $n^{\circ}$ 10.931/2004, a saber:

Art. 18. (...)

$\S 3^{\circ}$ - A CCI poderá ser emitida com ou sem garantia, real ou fidejussória, sob a forma escritural ou cartular.

Art. 19. A CCI deverá conter:

(...) 
III - a identificação do imóvel objeto do crédito imobiliário, com a indicação da respectiva matrícula no Registro de Imóveis competente e do registro de constituição de garantia, se for o caso;

(...)

Segundo Melhim Chalhub, a redação dos dispositivos acima transcritos permite cogitar a possibilidade de que a lei estaria abrindo uma nova linha de interpretação, segundo a qual se poderia entender que o crédito imobiliário pode ou não ser revestido de natureza real imobiliária ${ }^{12}$.

Podemos identificar três entendimentos distintos quanto aos requisitos necessários para que um crédito seja qualificado como imobiliário.

Um primeiro posicionamento defende que a natureza imobiliária decorre da vinculação do crédito a uma operação de construção ou aquisição imobiliária, sendo importante, portanto, a destinação dos recursos.

Há quem amplie esse rol admitindo como imobiliário quaisquer créditos oriundos ou garantidos pelos frutos e rendimentos de um imóvel ou negócio imobiliário, ou seja, créditos decorrentes da exploração do imóvel ou do financiamento de sua construção ou aquisição.

Por fim, uma visão mais flexível defende que a qualificação do crédito independe da sua origem e destinação, bastando apenas que o crédito seja garantido por um direito real de garantia.

Esse último entendimento amplia de tal forma as possibilidades de créditos imobiliários que até mesmo um financiamento para aquisição de um automóvel poderia ser enquadrado como crédito imobiliário bastando, para tanto, que fosse garantido por uma hipoteca, por exemplo.

\footnotetext{
${ }^{12}$ CHALHUB, MelhimNamem. Alienação Fiduciária, Incorporação Imobiliária e Mercado de Capitais, p. 515.
} 
Apesar das diversas possíveis interpretações, nas palavras de Melhim Chalhub “(...) a estruturação e o desenvolvimento de um mercado secundário de créditos imobiliários estável e duradouro, (...) só será possível a partir de práticas que confiram segurança jurídica e econômica ao investidor".

Nessa linha o mencionado autor defende que:

[...] é recomendável que o crédito imobiliário seja conceituado em função do vínculo real que prende certo imóvel à satisfação de determinado crédito, de modo a assegurar-se ao credor o direito de se apropriar do conteúdo econômico do imóvel em caso de mora ou inadimplemento do devedor, obviamente até o limite do valor do seu crédito.

E tendo-se em mente o propósito do novo sistema legislativo, de combinar a segurança das operações imobiliárias com a celeridade do mercado de capitais, não há dúvidas de que a noção de crédito imobiliário deve ser associada à ideia mesma de direito real, pois só assim operaria o binômio segurança + celeridade visado pela legislação ${ }^{13}$.

No âmbito das experiências práticas do mercado, desde 2002 a Comissão de Valores Mobiliários vêm enfrentando o tema.

Em recente decisão, proferida em 26.03.2013, a Comissão indeferiu o pedido de registro definitivo da oferta pública de distribuição da $289^{\mathrm{a}}$ série de CRI da $1^{\text {a }}$ emissão da Brazilian Securities Companhia de Securitização.

A operação objeto do Processo CVM RJ nº 2012/12177 contava com a seguinte estrutura: a Rede D’or São Luiz S.A., devedora da operação, emitiria debêntures que serviriam como lastro para a emissão de CRI. Nos termos da escritura de emissão das debêntures, a totalidade dos recursos captados no mercado seria destinada exclusivamente para a aquisição de terrenos, edificação e expansão de prédios hospitalares, não havendo qualquer destinação de recursos para a aquisição de máquinas, equipamentos ou demais bens relacionados à atividade comercial desenvolvida pela devedora.

${ }^{13}$ CHALHUB, Melhim Namem. Alienação Fiduciária, Incorporação Imobiliária e Mercado de Capitais, p. 517. 
As debêntures seriam integralmente subscritas e integralizadas pelo Banco BTG Pactual S.A., que na sequência emitiria uma CCI representativa das debêntures, que por sua vez seria transferida à Brazilian Securities, securitizadora responsável pela emissão dos CRI.

Enquanto a securitizadora defendia a natureza imobiliária do crédito sob o fundamento de que os recursos captados através da operação seriam destinados única e exclusivamente para fins imobiliários, o Colegiado, por unanimidade, manifestou-se contrariamente utilizando como critério a origem do fluxo de pagamento da operação.

Segundo a CVM, considerando que a devedora é uma rede hospitalar, a origem do seu fluxo de caixa, responsável pelo adimplemento da operação, não estaria relacionado aos imóveis, não sendo possível, portanto, a caracterização dos créditos como sendo de natureza imobiliária.

Essa decisão manteve o entendimento anteriormente manifestado pela CVM na apreciação do Processo CVM RJ nº 2002/3032, que pretendia o registro de emissão de CRI lastreados em créditos decorrentes de contratos de comercialização de energia elétrica, na medida em que os recursos captados também seriam destinados à ampliação e reforma de um imóvel.

Nesta oportunidade, o Colegiado entendeu que:

[...] para que créditos ditos imobiliários possam lastrear uma emissão de certificados de recebíveis imobiliários, seria necessário que tais recebíveis decorressem da exploração do imóvel ou do financiamento do imóvel, e não de uma atividade econômica exercida pela tomadora mediata dos recursos, mesmo que tal atividade seja realizada em um imóvel de propriedade desta. $\mathrm{Ou}$, como destaca a PJU, embora a geração de energia e sua comercialização possam constituir receita de uma "planta industrial", não pode tal receita ser considerada como um crédito imobiliário.

Dito de outro modo, parece-me que o crédito é imobiliário pela origem e não pela destinação ${ }^{14}$.

\footnotetext{
${ }^{14}$ Processo CVM RJ no 2002/3032, Relator Luiz Antônio de Sampaio Campos, julgado em 13.05.2003.
} 
Também é importante mencionar a decisão proferida no âmbito do Processo CVM RJ n 2001/1981, julgado em 14.05.2002, no qual o Diretor Relator Wladimir Castelo Branco Castro, se manifestou favoravelmente à possibilidade de emissão de CRI lastreados em créditos locatícios:

[...] devo concordar que a Lei 9.514/97 não trouxe uma definição para "crédito imobiliário", nem estabeleceu que a securitização só pode abarcar créditos oriundos de financiamentos imobiliários.

[...]

Uma interpretação "sistemático-restritiva" da Lei talvez indicasse que apenas créditos oriundos de financiamentos obtidos no âmbito do SFI poderiam lastrear CRIs.

[...] entendo que créditos decorrentes de locações comerciais podem ser securitizados nos termos da Lei 9.514/97, já que esta não veda expressamente tal modalidade, mesmo que tais créditos não se originem de operações de financiamento no âmbito do SFI ou fora dele.

Outra discussão enfrentada pela CVM, que foge um pouco ao tema referente à conceituação do que seja um crédito imobiliário, mas não menos importante, diz respeito à definição do momento em que o crédito é constituído e pode passar a servir como lastro para uma emissão de CRI.

Em 2007, no Processo CVM RJ n 2007/547, a CVM enfrentou a seguinte questão: é possível estruturar uma emissão de CRI com lastro no pagamento de aluguéis decorrente da celebração futura de contratos de locação sobre imóveis até então desocupados ou sobre imóveis que ainda virão a ser construídos através da futura expansão de um shopping center?

O Relator Marcelo Trindade, defendeu a diferenciação entre os termos crédito e direito creditório, ensinando que os direitos creditórios dizem respeito ao crédito futuro e ainda não constituído. Com base nessa classificação o ex-presidente indeferiu o pedido de registro de distribuição de CRI uma vez que, de acordo com o caput do artigo $8^{\circ}$, da Lei $\mathrm{n}^{\circ}$ $9.514 / 1997^{15}$, os CRI somente podem ser lastreados em créditos

\footnotetext{
${ }^{15}$ Art. $8^{\circ}$ A securitização de créditos imobiliários é a operação pela qual tais créditos são expressamente vinculados à emissão de uma série de títulos de crédito, mediante Termo de Securitização de Créditos, lavrado por uma companhia securitizadora, do qual constarão os seguintes elementos: (...).
} 
imobiliários, não se admitindo o uso de direitos creditórios como lastro.

Veja-se:

[...] concordo em que os ativos passíveis de securitização por meio de CRI são os créditos imobiliários, e não os direitos creditórios de origem imobiliária adotando-se a distinção antes referida. Isto é: é preciso que o crédito esteja constituído, e seu valor seja determinado, para que se possa proceder à emissão de CRI com base nele. E isto se dá porque o CRI é um título de crédito criado por lei, cujas características não podem ser alteradas pela CVM.

Nada impede, naturalmente, que operações com base em créditos futuros sejam estruturadas através de FIDC, pois a regulamentação da CVM expressamente o admite, observadas as ressalvas antes feitas quanto à prévia existência de uma relação jurídica, como previsto na Instrução $444 / 06^{16}$.

Essa decisão reafirmou o entendimento proferido em 2005, no julgamento do Processo CVM RJ no 2004/6913, quando o também Relator Marcelo Trindade, analisou a estrutura básica dos fundos de investimento em direitos creditórios:

Os FIDC são, na forma da Instrução CVM 356/01, condomínios que têm por objeto direitos creditórios. A regulamentação refere-se a direitos creditórios, e não a créditos, porque frequentemente os FIDC formam-se com a finalidade de adquirir créditos futuros, ainda não constituídos. Assim, são captados recursos dos condôminos (cotistas), sendo tais recursos destinados, pelo administrador, ao longo do período de existência do FIDC, à aquisição de créditos que vão sendo constituídos (e quitados) durante aquele período.

Tais créditos futuros, por sua vez, podem representar (e frequentemente representam), quando de sua cessão para o fundo, a contraprestação pela entrega futura de produtos ou serviços. Tais créditos são normalmente denominados de não performados, em oposição àqueles (performados) em que já existe uma obrigação de pagamento por parte do devedor desvinculada de qualquer conduta do credor. A Instrução CVM 356/01 refere-se a tais créditos não performados no $\S 8^{\circ}$ do art. 40, para condicionar a concessão de registro automático de um FIDC pela CVM à existência de garantia de seguro, nesses $\operatorname{casos}^{17}$.

É notório que a discussão envolvendo o conceito de crédito imobiliário é extremamente vasta e controversa e ainda requer muitos debates, seja no âmbito doutrinário como no âmbito jurisprudencial. O que nos fica claro é que apenas com a prática reiterada poderemos consolidar o conceito do que sejam créditos imobiliários, trazendo maior segurança jurídica às operações de securitização.

\footnotetext{
${ }^{16}$ Processo CVM RJ n ${ }^{\text {o }}$ 2007/547, Relator Marcelo Fernandez Trindade, julgado em 10.07.2007.

${ }^{17}$ Processo CVM RJ no 2004/6913, Relator Marcelo Fernandez Trindade, julgado em 04.10.2005.
} 


\subsection{Cédula de Crédito Imobiliário}

Ultrapassada a discussão quanto à definição dos créditos imobiliários, passa-se a analisar a segunda etapa de uma emissão do CRI, qual seja, a emissão dos títulos representativos do crédito.

A Lei $n^{\circ}$ 10.931/2004 instituiu no ordenamento jurídico brasileiro as chamadas cédulas de crédito imobiliário, um novo título de crédito para representar especificamente créditos imobiliários, sejam eles hipotecários, fiduciários, oriundos de contratos de locação, contratos de compra e venda, cessão de direito de superfície.

Nos termos do $\S 1^{\circ}$, do artigo $18^{18}$, da mencionada lei, a CCI é emitida pelo titular do crédito - não havendo qualquer restrição legal quanto à figura do emissor, podendo ser instituição financeira, pessoa jurídica ou até mesmo pessoa física - e será integral, quando representar a totalidade do crédito, ou fracionária, quando representar apenas parte dele, ficando o somatório das CCI fracionárias limitado ao valor total do crédito que elas representam.

A importância da emissão da CCI reside no fato de que sem ela a circulação do crédito ficaria prejudicada. É ela que viabiliza a segregação do risco, pois os direitos de crédito de titularidade da sociedade originadora serão transferidos para a securitizadora através da cessão e transferência da CCI. Veja-se o ensinamento de Melhim Chalub:

[a CCI] visa dar celeridade à circulação do crédito, simplificando e reduzindo os custos das operações de captação de recursos para o mercado imobiliário, notadamente para a operação de securitização de créditos, que, como se sabe, realiza-se mediante cessão do crédito a uma companhia securitizadora e subsequente emissão de títulos lastreados e créditos imobiliários ${ }^{19}$.

\footnotetext{
${ }^{18}$ Art. $18(\ldots)$

$\S 1^{\circ}$ A CCI será emitida pelo credor do crédito imobiliário e poderá ser integral, quando representar a totalidade do crédito, ou fracionária, quando representar parte dele, não podendo a soma das CCI fracionárias emitidas em relação a cada crédito exceder o valor total do crédito que elas representam.

${ }_{19}$ CHALHUB, Melhim Namem. Da Incorporação Imobiliária. $3^{a}$ ed.. Rio de Janeiro: Renovar, 2012, p. 273.
} 
Ainda segundo o autor, "a grande inovação (...), no que tange a circulação do crédito, é a criação da CCI escritural, eu se ajusta plenamente às modernas condições de utilização de meios eletrônicos para realização de negócios". Por esse mecanismo a negociação e a cessão do crédito ocorre através dos sistemas eletrônicos de registro e liquidação financeira de títulos, agilizando ainda mais as transações.

Vale ressaltar que as normas aplicáveis à securitização imobiliária não exigem a emissão de CCI como uma etapa preliminar para a emissão de CRI. A única obrigação legal verificada diz respeito à existência do crédito de natureza imobiliária. Se o referido crédito irá ou não ser representado por uma CCI, dependerá da estrutura de cada operação ${ }^{20}$. Admitindo-se que não haja emissão do referido título de crédito, a segregação dos recebíveis será feita mediante uma simples cessão de crédito, instituto previsto no Direito Civil.

Ainda que legal e juridicamente seja possível a estruturação de uma emissão de CRI sem representação dos créditos imobiliários através de CCI, deve-se levar em conta a importância da presença da cédula de crédito imobiliário nas operações.

$\mathrm{Na}$ qualidade de título de crédito, a presença da CCI confere aos investidores e à operação de uma forma geral, segurança jurídica na medida em que a ela se aplica um dos princípios mais importante do direito cambiário, qual seja, o princípio da autonomia. O mencionado princípio implica no reconhecimento do título como "constitutivo de direito novo, autônomo, originário e inteiramente desvinculado da relação causal"21.

\footnotetext{
${ }^{20}$ A existência da possibilidade de emissão de CRI sem que haja emissão prévia de CCI, ainda que não verificada na prática, é reforçada pelas palavras de Melhim Chalub, que admite que os créditos imobiliários não sejam representados por CCI. Veja-se: "quando os créditos imobiliários forem representados por Cédula de Crédito Imobiliário, o termo poderá ser emitido em forma simplificada, bastando que sejam nele consignados o valor de cada crédito, o número e a série das CCI e a entidade custodiante dos créditos". (CHALHUB, Melhim Namem. Alienação Fiduciária, Incorporação Imobiliária e Mercado de Capitais, p.485).

${ }^{21}$ ROSA JUNIOR, Luiz Emygdio Franco da. Títulos de Crédito. $7^{\mathrm{a}}$ ed. Revista e atualizada. Rio de Janeiro: Renovar, 2011, p. 67.
} 
Sendo assim, daí decorre o subprincípio da inoponibilidade da exceção pessoal ao terceiro de boa fé.

Segundo o Professor Luiz Emygdio "este subprincípio visa proteger o terceiro adquirente de boa-fé para facilitar a circulação do título, porque quanto mais estiver protegido, mais facilmente o título circulará" ${ }^{22}$.

Este benefício da desvinculação do negócio subjacente não será aproveitado caso se opte pela realização de uma cessão civil de créditos. É com o intuito de aumentar a confiança do investidor e dar-lhe maior segurança jurídica que, na prática, as operações contam, inicialmente, com a representação dos créditos imobiliários através de uma CCI.

\subsection{Tipos de Emissão de CCl}

Atualmente no mercado imobiliário, além dos tradicionais contratos de locação, compra e venda de imóvel e financiamento imobiliário, algumas modalidades de negócios têm sido estruturadas de forma a possibilitar a constituição de crédito imobiliário para posterior securitização através da emissão de CRI.

Tais estruturas contam com a utilização de contratos atípicos, que não possuem legislação específica. Independentemente disso, essas modalidades de operações estruturadas têm se tornado cada vez mais comuns e ganhado cada vez mais espaço no mercado imobiliário. Passaremos a analisar cada uma dessas modalidades.

\footnotetext{
${ }^{22}$ ROSA JUNIOR, Luiz Emygdio Franco da. Títulos de Crédito, p. 70.
} 


\subsubsection{Sale and Leaseback}

O próprio nome dado a esta modalidade de negócio imobiliário já indica a sua estrutura, que basicamente envolve duas etapas: (i) a aquisição de um imóvel pelo investidor; e (ii) a subsequente locação ao antigo proprietário.

Essa estrutura foi objeto de análise do Capítulo 3, tendo em vista que uma das suas principais vantagens é liberar o capital do antigo proprietário, anteriormente parado como ativo imobilizado (na medida em que o imóvel constitui patrimônio da sociedade), permitindo sua aplicação em investimentos parra o próprio negócio, sem, contudo, deixar de usufruir o imóvel, em razão da celebração do contrato de locação.

Para o investidor, o contrato de locação significa a certeza de retorno do capital utilizado na aquisição do imóvel, na medida em que o antigo proprietário fica obrigado ao pagamento mensal de aluguéis.

\subsubsection{Built to Suit}

Podemos dizer que em certa medida o contrato built to suit é caracterizado como uma modalidade de locação, na medida em que possui elementos jurídicos que constituem a relação locatícia. Até a edição da Lei $\mathrm{n}^{\mathrm{o}}$ 12.744, de 19 de dezembro de 2012, esta espécie de contrato era considerada como negócio atípico, tendo em vista algumas particularidades dessa modalidade de contratação.

Uma operação built to suit conta com as figuras das sociedades contratante e contratada. A sociedade contratante é aquela que busca um imóvel para se instalar e realizar seus negócios. No entanto, o imóvel deve atender todas as necessidades e especificidades exigidas por sua atividade. Para evitar altos investimentos financeiros na aquisição, reforma e 
adaptações de um imóvel, a sociedade contratante "busca um investidor/empreendedor que tenha interesse em investir na compra do terreno e na construção da edificação específica, a fim de locar o referido imóvel para esta sociedade" ${ }^{23}$. Este investidor/empreendedor, que atuará na qualidade de sociedade contratada, pode ser uma incorporadora ou uma construtora, que tenham como parte dos seus negócios o investimento em empreendimentos imobiliários, ou até mesmo um fundo de investimento imobiliário.

Sendo assim, a sociedade contratada adquire o terreno indicado pela sociedade contratante, realiza a edificação de acordo com as especificações determinadas e ao final da obra, com a entrega do empreendimento, o aluga para a contratante, de forma a lhe ceder o uso do imóvel.

É importante destacar que essa locação possui um longo prazo, variando entre 10 e 15 anos. Esse prazo extenso se justifica por dois motivos, primeiro, porque será através do pagamento dos aluguéis que a sociedade contratada irá obter o retorno dos investimentos feitos com a aquisição e construção do imóvel, segundo porque assegurará à contratante a utilização do imóvel construído sob medida para ela.

A estrutura contratual dos negócios built to suit envolve apenas três etapas, quais sejam, (i) o instrumento de aquisição do terreno; (ii) a contratação da construção da edificação a ser realizada no terreno, sob determinadas especificações; e (iii) a celebração do contrato de locação entre a sociedade contratada e a contratante.

As peculiaridades que envolvem os instrumentos dessa modalidade de negócio, tornando-o atípico, são (i) a forte ingerência da sociedade contratante sobre a construção do empreendimento, cabendo à ela determinar todas as especificações e parâmetros a serem seguidos pela

\footnotetext{
${ }^{23}$ CAMARGO, Cristiane Bueno; SISTI, Carlos Eduardo Poli; FERREIRA, Rogéria Cristina. Built to Suit, Direito Real de Superfície e Sale and Leaseback, uma Análise Comparativa, p. 2.
} 
sociedade contratada; e (ii) a celebração do contrato de locação de um imóvel ainda não existente. É importante notar que sem a celebração antecipada da locação o negócio como um todo fica prejudicado, pois essa contratação a priori é a garantia que a sociedade contratada tem do retorno dos investimentos feitos para a aquisição e construção do imóvel. Porém, a locação é celebrada com condição suspensiva, passando a vigorar somente após (i) a aprovação pelos órgãos governamentais dos projetos de construção do imóvel; (ii) a construção do empreendimento de acordo com o projeto definido e aprovado pela contratante e sob responsabilidade e custo da contratada; e (iii) a obtenção do certificado de ocupação.

Por fim, cabe mencionar que a sociedade contratada poderá antecipar o retorno dos seus investimentos através da securitização. O lastro para emissão de CRI será o crédito existente contra a sociedade contratada oriundo do contrato de locação.

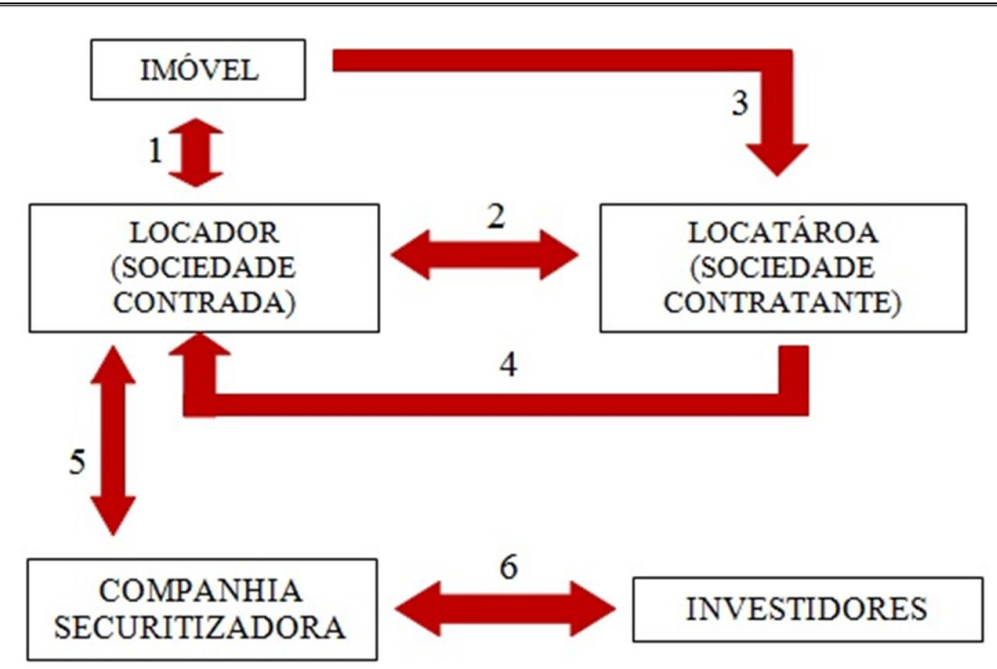

Estrutura de uma operação built to suit: 1. Aquisição do imóvel por parte da sociedade contratada; 2. Celebração do contrato de construção sob encomenda e do contrato de locação com condição suspensiva; 3. Finalização da construção e entrega do empreendimento; 4. Início da locação e pagamento dos aluguéis ao locador; 5. Emissão de CCI pelo locador com lastro nos créditos locatício e cessão onerosa para companhia securitizadora; 6. Emissão de CRI pela companhia securitizadora e subscrição dos títulos pelos investidores. 


\subsubsection{Direito de Superfície}

Previsto no Código Civil nos artigos 1.369 a 1.377, o direito de superfície caracteriza-se como direito real de fruição ou gozo sobre coisa alheia. Este direito confere a uma ou mais pessoas (superficiário) o direito de construir ou plantar em terreno alheio, sem que haja, contudo, transferência da propriedade.

Em uma operação imobiliária estruturada com base na concessão do direito de superfície o proprietário de um imóvel concede ao superficiário o direito de usar, construir e explorar a superfície de sua propriedade, recebendo em contraprestação uma remuneração cuja periodicidade poderá ser mensal, anual ou vinculada à receita a ser gerada pelo uso da superfície ${ }^{24}$.

O superficiário é o empreendedor ou investidor que irá realizar algum tipo de construção no terreno para, posteriormente, através da celebração de um contrato de locação, obter retornos com a exploração do empreendimento edificado.

O locatário poderá ser um terceiro, totalmente desvinculado da operação ou poderá ser o próprio proprietário do terreno, que objetivando evitar os custos com as obras, utiliza essa estrutura de operação. Podemos inclusive imaginar uma situação em que a cessão do direito de superfície seja seguida da celebração de um contrato built to suit, analisado no item anterior, caso o proprietário necessite de uma construção feita sob medida.

Da mesma forma que na operação built to suit, o empreendedor superficiário poderá se valer da securitização para antecipar os recursos dos investimentos feitos na aquisição da superfície e na realização das obras, bastando, para tanto, que transfira a uma companhia securitizadora os créditos dos quais é titular em razão da celebração do contrato de locação.

\footnotetext{
${ }^{24} \mathrm{O}$ artigo 1.370 do Código Civil prevê a possibilidade da cessão da superfície a título gratuito, no entanto, para fins do presente trabalho, esta hipótese não nos interessa.
} 
A securitizadora emitira CRI no mercado, destinando os recursos captados ao pagamento pela aquisição dos créditos.

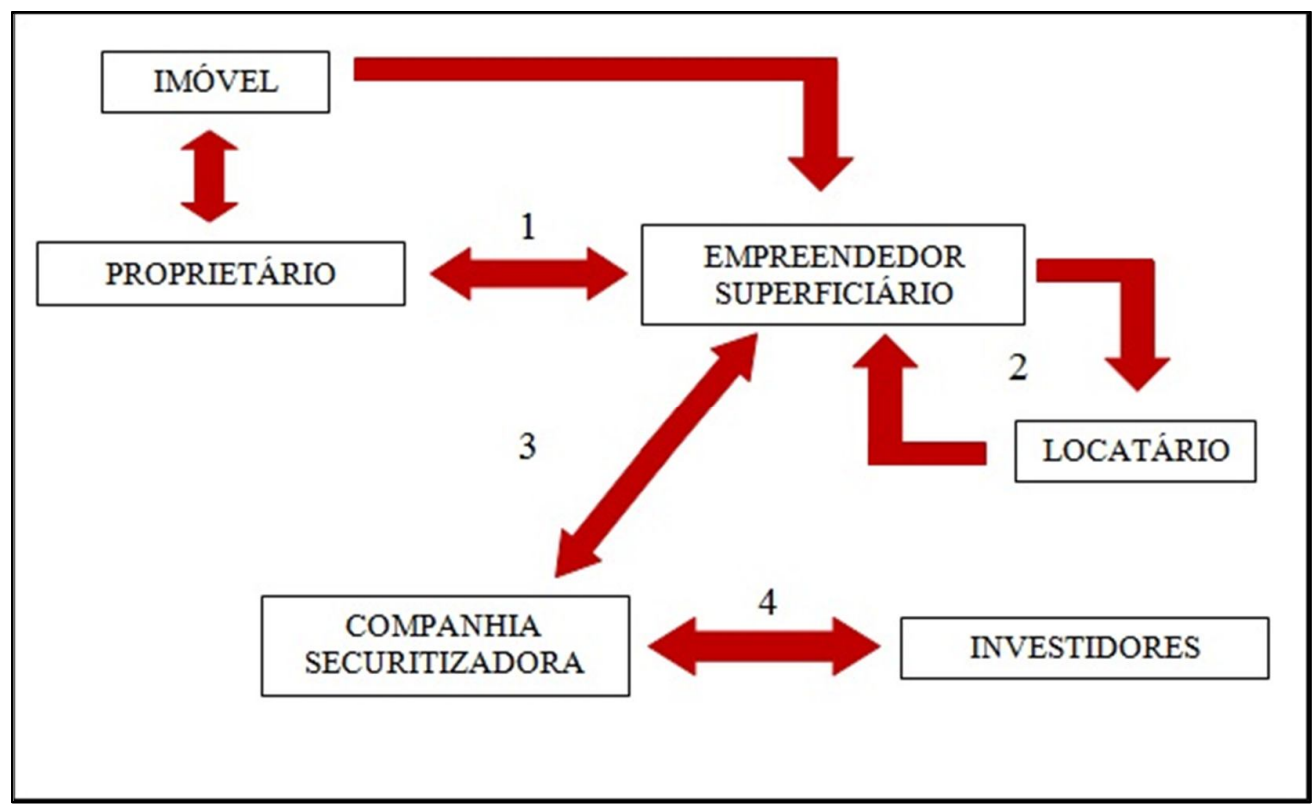

Estrutura de uma operação de direito real de superfície: 1. Celebração da escritura de concessão de direito real de superfície; 2. Após a execução das obras o superficiário celebra contrato de locação com um terceiro, que se obriga ao pagamento de aluguéis; 3. O superficiário sede à securitizadora os créditos oriundos do contrato de locação; 4. A securitizadora emite CRI com lastro dos créditos adquiridos, anteriormente de titularidade do superficiário, que são subscritos pó investidores.

\subsection{Securitização das $\mathrm{CCl}$ e Emissão dos CRI}

Após a constituição do crédito imobiliário e a emissão, pela sociedade originadora, das CCI representativas desse crédito, o passo seguinte é a cessão e transferência dessas CCI para a companhia securitizadora.

Essa transferência representa a segregação do risco, tendo em vista que é neste momento que os créditos deixam de pertencer ao patrimônio da sociedade originadora e passam a ser de titularidade da companhia securitizadora.

Além disso, sem a aquisição dos créditos imobiliários a operação de securitização não pode ser efetivada, tendo em vista que o artigo $3^{\circ}$, da Lei 
$\mathrm{n}^{\text {o }}$ 9.514/1997 prevê expressamente que as companhias securitizadoras "terão por finalidade a aquisição e securitização desses créditos".

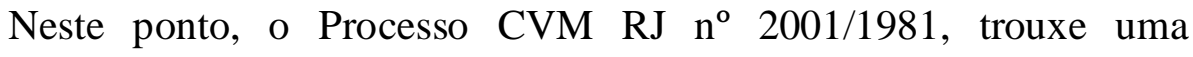
discussão bastante interessante: a cessão do crédito é etapa essencial e indispensável da securitização? Poderia ser estruturada uma operação onde a própria companhia securitizadora fosse a sociedade originadora do crédito?

No caso do mencionado processo a securitizadora era a proprietária do imóvel e iria construir um galpão mediante obtenção de um financiamento imobiliário para posterior locação. Os CRI seriam emitidos com lastro nos créditos imobiliários decorrentes dos contratos de locação a serem celebrados entre a própria securitizadora e terceiros locatários.

Segundo o Diretor Relator Wladimir Castelo Branco Castro, a aquisição dos créditos, por fazer parte da definição de companhia securitizadora, é essencial na securitização. No entanto, entendendo haver em nosso ordenamento jurídico duas modalidades distintas de aquisição, aquisição originária e secundária, considerou que o caso objeto do processo se caracterizava como uma aquisição originária. E estando satisfeito o requisito legal da "aquisição", não haveria qualquer impedimento à realização da operação. Veja-se:

Entendo ser possível depreender que a finalidade de aquisição de créditos imobiliários, imposta pela Lei às companhias securitizadoras, não significa necessariamente que tais aquisições devam ocorrer apenas por meio de transferência de créditos imobiliários. Tanto a definição vernacular quanto a jurídica dadas para o termo aquisição abrangem mais possibilidades do que a simples aquisição por transferência - aí incluída a cessão. A propósito, no direito civil, a aquisição apresenta duas modalidades, aquisição originária - realizada pelo primeiro dono da coisa, e aquisição derivada - realizada quando a coisa, tendo dono, é transferida deste para outro.

Tenho como razoável, portanto, considerar-se a locação de imóvel como uma forma de aquisição de créditos locatícios pelo locador, de maneira assemelhada à aquisição originária do direito civil, não havendo, a meu juízo, quanto a este 
aspecto, dissonância entre a estrutura de securitização proposta pelo consulente e a disposição legal do art. $3^{\circ}$ acima transcrito ${ }^{25}$.

Quanto à possibilidade de a securitizadora ser também a originadora dos créditos o Relator se manifestou de forma favorável ressalvando, contudo, a necessidade de que os "créditos sejam segregados patrimonialmente com base no regime fiduciário (...) e sejam atendidas as demais exigências desta Lei [Lei no 9.514/1997]”.

Seja originária ou secundária, após a aquisição dos créditos imobiliários cabe à securitizadora vincular tais créditos aos CRI que serão emitidos e colocados no mercado financeiro. Essa etapa de vinculação é a securitização propriamente dita, que nos termos do artigo $8^{\circ}$ da Lei $n^{\circ}$ 9.514/1997 "é a operação pela qual tais créditos são expressamente vinculados à emissão de uma série de títulos de créditos".

Este vínculo é estabelecido através do termo de securitização, instrumento lavrado pela própria securitizadora que deve conter as seguintes informações: (i) identificação do devedor e o valor nominal de cada crédito que lastreie a emissão, com a individualização do imóvel a que esteja vinculado e a indicação do Cartório de Registro de Imóveis em que esteja registrado e a respectiva matrícula, bem como a indicação do ato pelo qual o crédito foi cedido; (ii) identificação dos títulos emitidos; (iii) constituição de outras garantias de resgate dos títulos da série emitida, se for o caso.

Ocorrida a emissão e subscritos os CRI pelos investidores, as etapas básicas de uma operação de securitização imobiliária são concluídas.

\footnotetext{
${ }^{25}$ Processo CVM RJ no 2001/1981, Relator Wladimir Castelo Branco Castro, julgado em 14.05.2002.
} 


\subsection{Mecanismos de Garantias}

Como já restou demonstrado, cada operação possui suas particularidades, levando-se em conta a sua estrutura, as características da sociedade originadora e seus objetivos. No entanto, algumas formas de prestação de garantias são recorrentemente utilizadas da prática. Passaremos a analisar cada uma delas.

\subsubsection{Aval}

É bastante usual que os sócios, pessoas físicas ou jurídicas, da sociedade originadora dos créditos imobiliários, prestem garantia fidejussória no âmbito da operação, se obrigando autônoma, pessoal e incondicionalmente a garantir, total ou parcialmente, no vencimento, o pagamento da CCI nas condições nela estabelecidas.

Nas palavras do Professor Luiz Emygdio "a importância do aval decorre da sua função de reforço das garantias já existente no título, facilitando a sua circulação pela maior segurança que confere ao portador no que toca ao seu pagamento" 26 .

Discussão interessante envolvendo o aval diz respeito à possibilidade de limitação da responsabilidade do avalista. Enquanto o parágrafo único do artigo 897 do Código $\mathrm{Civil}^{27}$ veda expressamente essa possibilidade, algumas normas específicas de direito cambiário permitem a concessão do aval parcial $^{28}$.

\footnotetext{
${ }^{26}$ ROSA JUNIOR, Luiz Emygdio Franco da. Títulos de Crédito, p. 283

${ }^{27}$ Art. 987 (...) Parágrafo único - É vedado o aval parcial.

${ }^{28}$ Decreto $\mathrm{n}^{\circ} 57.595 / 1966$ - art. 25 , al. $1^{\circ}$ "O pagamento de um cheque pode ser garantido no todo ou em parte do seu valor por um aval".

Anexo I, LUG - art. 30, al. $1^{\text {a } ~ " O ~ p a g a m e n t o ~ d e ~ u m a ~ l e t r a ~ p o d e ~ s e r ~ n o ~ t o d o ~ o u ~ e m ~ p a r t e ~ g a r a n t i d o ~}$ por aval".

Lei $n^{\circ} 7.357 / 1985$ - art. 29 "O pagamento do cheque pode ser garantido, no todo ou em parte, por aval prestado por terceiros, exceto o sacado, ou mesmo por signatário do título”.
} 
De acordo com os ensinamentos do Professor Luiz Emygdio as normas de direito cambiário permitem o aval parcial levando em consideração o direito que as partes envolvidas têm de limitar as suas obrigações. Pondera que para a figura do credor é mais vantajoso ser portador de um título com garantia parcial, do que de um título sem qualquer garantia. Além disso, esclarece que "nada obsta que o pagamento do título seja garantido por pluralidade de avais parciais",29.

Por outro lado, quem entende pela vedação do aval parcial, justifica seu posicionamento levantando a impossibilidade de o avalista que quitou sua obrigação parcial exercer seu direito de regresso sem deter o título, e caso o detenha obstará que o credor receba cambiariamente o saldo ${ }^{30}$.

Em contraposição a este argumento, o Professor Luiz Emygdio ensina que:

[...] se o avalista honrar seu aval limitado, não tem o direito de exigir que o título lhe seja entregue porque o portador dele necessita para cobrar o valor remanescente. No entanto, o avalista pode exigir que conste do título a efetivação do pagamento parcial e que dele lhe seja dada quitação mediante recibo em separado, constando todos os elementos necessários para identificar o título [...] 31 .

Por fim, é importante abordar as diferenças existentes entre o aval e a fiança. Ambos os institutos se caracterizam como espécie de garantia fidejussória, ou seja, são espécies de garantias pessoais, no entanto, não se confundem.

Enquanto o aval é instituto próprio do direito cambiário e somente pode garantir obrigações de pagamento decorrentes de títulos de crédito, a fiança é regulada pelo direito comum e pode garantir qualquer tipo de obrigação, inclusive uma obrigação cambiária. Além disso, os institutos também diferem quanto à forma, uma vez que a fiança pode ser prestada no

\footnotetext{
${ }^{29}$ ROSA JUNIOR, Luiz Emygdio Franco da. Títulos de Crédito, p. 294.

30 TEPEDINO, Gustavo; BARBOZA, Heloisa Helena; BODIN DE MORAES, Maria Celina. Código Civil interpretado conforme a Constituição da República. Vol. II. Rio de Janeiro: Renovar, 2006, p.771.

${ }^{31}$ ROSA JUNIOR, Luiz Emygdio Franco da. Títulos de Crédito, p. 295.
} 
mesmo instrumento em que a obrigação garantida é constituída ou em documento separado. O aval por sua vez, por força dos artigos 898 do Código Civil e 31, alínea $1^{\circ}$ da LUG 32, deverá ser lançado no próprio título garantido. $\mathrm{O}$ aval somente garante obrigações líquidas, tendo em vista ser uma das características dos títulos de crédito. Já a fiança poderá garantir obrigação líquida ou ilíquida. $\mathrm{O}$ avalista se obriga perante pessoa indeterminada, tendo em vista a possibilidade de circulação do título de crédito, respondendo perante o portador do título na data do seu vencimento. O fiador, por sua vez, obriga-se perante pessoa determinada, que é o credor da obrigação. Ademais, a fiança se caracteriza como sendo uma obrigação acessória, e neste sentido será nula caso a obrigação principal do devedor também o seja. Contrariamente, o aval se caracteriza como obrigação autônoma e, portanto, subsistirá ainda que a obrigação avalizada seja nula, salvo se a nulidade decorrer de vício de forma.

\subsubsection{Hipoteca e Alienação Fiduciária}

Além da garantia fidejussória prestada através do aval, as operações de emissão de CRI também podem contar com garantias reais. A hipoteca e a alienação fiduciária são frequentemente utilizadas e apesar de recaírem sobre bens imóveis, se caracterizam como tipos distintos de garantia real, mas mesmo assim são muitas vezes confundidos.

Nas palavras de Carlos Roberto Gonçalves "a hipoteca é concebida e regulada, de modo geral, como direito real de garantia que consiste em sujeitar um imóvel, preferencialmente, ao pagamento de uma dívida de outrem, sem retirá-la da posse do dono" ${ }^{33}$. Esta é uma das principais vantagens da garantia hipotecária para o devedor, pois a posse e a

\footnotetext{
${ }^{32}$ Código Civil. Art. 898. O aval deve ser dado no verso ou no anverso do próprio título. LUG. Art. 31. O aval é escrito na própria letra ou numa folha anexa.

${ }^{33}$ GONÇALVES, Carlos Roberto. Direito Civil Brasileiro. Direito das Coisas. Vol. 5. $5^{\text {a }}$ ed.. São Paulo: Saraiva, 2010, p. 589.
} 
propriedade do imóvel hipotecado permanecem com o seu titular. Apenas em caso de inadimplemento haverá a perda da posse, hipótese na qual o imóvel será vendido judicialmente e os recursos arrecadados com a alienação serão revertidos para o pagamento da dívida.

Diferentemente, quando o imóvel é alienado fiduciariamente em garantia "o credor torna-se titular do domínio resolúvel sobre a coisa objeto da garantia, permanecendo sob seu domínio até que o devedor pague a dívida" ${ }^{34}$. A alienação fiduciária, do ponto de vista do credor, é mais vantajosa, uma vez que o imóvel dado em garantia é transferido para o seu patrimônio, impedindo que o bem venha a responder pelas demais obrigações do devedor em caso de sua eventual insolvência. $\mathrm{O}$ mesmo não ocorre na garantia hipotecária. $\mathrm{Na}$ hipótese de falência do devedor hipotecário, o imóvel dado em garantia será arrecadado pelo administrador judicial e integrará os ativos da massa falida. O credor hipotecário não terá nenhum tipo de privilégio, concorrendo com os demais credores de acordo com a ordem legal de preferência.

Outra vantagem do ponto de vista do credor está relacionada à forma de execução da garantia. Enquanto a execução da hipoteca é extremamente morosa, pois depende da realização de leilão judicial para que o imóvel seja alienado, a execução da garantia fiduciária se procedente no registro de imóveis, mediante consolidação da propriedade em nome do credor fiduciário, independendo de intervenção judicial.

${ }^{34}$ CHALHUB, Melhim Namem. Negócio Fiduciário. 4ª ed.. Rio de Janeiro: Renovar, 2009, p. 222 e 223 . 


\subsubsection{Cessões Fiduciárias}

Outra garantia frequentemente utilizada nas operações de emissão de CRI é a cessão fiduciária. Para Melhim Chalhub:

A fidúcia encerra a ideia de uma convenção pela qual uma das partes, o fiduciário, recebendo da outra (fiduciante) a propriedade de um bem, assume a obrigação de dar-lhe determinada destinação e, em regra, de restituí-lo uma vez alcançado o objetivo enunciado na convenção ${ }^{35}$.

A grande vantagem da garantia fiduciária está no fato de que o bem ou direito cedido fiduciariamente passa a pertencer ao patrimônio do credor fiduciário, até que a obrigação seja adimplida. Desta forma, o credor impede que os bens dados em garantias sejam utilizados para adimplir outras obrigações do devedor em caso de insolvência.

Nos termos do artigo 1.361 do Código Civil, podem ser objeto de cessão fiduciária quaisquer bens e direitos, contanto que sejam infungíveis A infungibilidade se caracteriza pela particularidade, não sendo passíveis de substituição por outro bem da mesma espécie, quantidade e qualidade.

$\mathrm{Na}$ prática, as operações de securitização imobiliária muito frequentemente contam com três espécies de cessão fiduciária em garantia.

A primeira delas é a cessão fiduciária de quotas ou ações da sociedade originadora ou de outra sociedade do grupo. Sobre essa espécie de negócio fiduciário, Melhim Chalub ensina que:

A permissão para negociação fiduciária de ações inspira-se no princípio de que o negócio fiduciário, como instituto de ampla aplicação, abrange a transmissão de bens ou direitos, bem como a assunção de obrigações abstratas. Nesse caso, a alienação fiduciária enseja a criação da figura do acionista fiduciário, o qual observa Ferrara, 'não é fictício, teste de ferro ou mandatário, mas verdadeiro acionista, proprietário efetivo da ação, quer nas relações internas quer nas relações externas, podendo, portanto, intervir nas assembleias e exercitar direitos sociais $^{36}$.

\footnotetext{
${ }^{35}$ CHALHUB, Melhim Namem. Negócio Fiduciário, p. 9.

${ }^{36}$ Ibid. p. 167.
} 
Essa garantia envolve não apenas a celebração do contrato de cessão fiduciária das quotas ou ações, mas também o registro de uma alteração do contrato social da sociedade emissora das quotas, no caso de uma sociedade limitada, ou a averbação, no livro de Registro de Ações Nominativas ou nos livros da instituição financeira, caso as ações sejam, respectivamente, nominativas ou escriturais. Essas providências permitem que o negócio fiduciário seja oponível perante terceiros, tratando-se, portanto, de mais uma importante proteção ao credor.

A cessão fiduciária de recebíveis, outra modalidade de negócio fiduciário, é extremamente utilizada nas operações de securitização. Os recebíveis, via de regra, têm sua origem no fluxo de pagamento decorrente das vendas das unidades autônomas de empreendimentos imobiliários. Em outras palavras, a sociedade originadora responsável pela incorporação do empreendimento residencial, por exemplo, inicia a venda das unidades antes mesmo de iniciar as construções. No entanto, ao invés de securitizar os créditos dos quais é titular na qualidade de vendedoras dos imóveis, ela contraí um financiamento imobiliário para dar inicio às obras e como garantia cede fiduciariamente à instituição financiadora os recursos oriundos da exploração comercial do empreendimento.

$\mathrm{Na}$ prática, os contratos de compra e venda celebrados entre a sociedade originadora e os terceiros adquirentes já possuem uma previsão específica permitindo a possível cessão dos créditos e determinando que os adquirentes dos imóveis deverão efetuar o pagamento ao cessionário dos créditos.

Dessa forma, os recursos são depositados em uma conta vinculada, sob a qual a sociedade originadora não tem direito de livre movimentação, dependendo da anuência do agente fiduciário para realizar qualquer tipo de operação.

Na medida em que as obrigações são adimplidas, o agente fiduciário permite que a sociedade originadora tenha acesso aos recursos depositados na conta vinculada. Em hipótese de inadimplemento, o agente fiduciário 
fica autorizado a utilizar os valores depositados na conta para quitar as parcelas devidas no âmbito da operação de securitização, garantindo aos investidores o fluxo de pagamento dos rendimentos.

Por fim, também é comum que as operações de securitização prevejam a cessão fiduciária total ou parcial dos recursos provenientes da subscrição pelos investidores dos CRI. Na prática isso significa que a sociedade originadora que se utiliza do mecanismo da securitização para financiar seu empreendimento imobiliário, não terá acesso imediato a totalidade dos recursos captados junto ao mercado. É comum que os recursos da subscrição sejam depositados também em uma conta vinculada (diferente da conta vinculada destinada aos recebíveis da comercialização dos empreendimentos). A liberação geralmente acontece mensalmente, mediante apresentação de relatório acerca dos andamentos da obra pela sociedade originadora ao agente fiduciário da operação. Na medida em que a construção e as obras se encontram dentro do planejamento e do cronograma, o agente fiduciário libera os recursos para utilização pela

sociedade originadora. Caso haja qualquer problema com o desenvolvimento do projeto, o agente fiduciário tem poderes para impedir que os recursos sejam movimentados.

\subsubsection{Patrimônio Separado}

Após a emissão da cédula de crédito imobiliário pela sociedade originadora e sua transferência para a companhia securitizadora, está última passa a ser a titular dos créditos imobiliários envolvidos na operação. Partindo deste ponto, a Lei $\mathrm{n}^{\circ} 9.514 / 1997$, em seu artigo $9^{\circ}$ e seguintes, instituiu o chamado regime fiduciário, do qual decorre o instituto do patrimônio separado. 
Nos termos da referida lei, a companhia securitizadora, na qualidade de titular dos créditos, através do termo de securitização, poderá instituir regime fiduciário sobre os créditos imobiliários que lastreiam a emissão dos CRI, cedendo os referidos créditos ao agente fiduciário ${ }^{37}$, em benefício dos investidores subscritores do CRI.

A instituição do regime fiduciário implica na constituição de um patrimônio separado, composto pela totalidade dos créditos submetidos ao regime fiduciário que lastreiam a emissão do CRI, e que não se confunde com o patrimônio da companhia securitizadora. Tanto é assim, que o artigo 12 da Lei $n^{\circ} 9.514$ prevê expressamente que “(...) incumbirá à companhia securitizadora administrar cada patrimônio separado, manter registros contábeis independentes em relação a cada um deles e elaborar e publicar as respectivas demonstrações financeiras".

Além disso, os créditos pertencentes ao patrimônio separado estão vinculados exclusivamente à liquidação dos CRI a que estiverem afetados, respondendo somente pelas obrigações decorrentes desta operação. Sendo assim, eventual insolvência da companhia securitizadora não afetará os patrimônios separados que tenha constituído (parágrafo único, artigo 15).

Nas palavras de Uinie Caminha:

Seguramente, a principal utilidade prática dos conceitos de patrimônio geral, separado e autônomo, é a delimitação da responsabilidade de seus titulares, ou seja, determinar quais elementos ativos respondem por determinadas obrigações $^{38}$.

Inicialmente, a administração do patrimônio separado caberá à própria companhia securitizadora. No entanto, caso os bens sejam insuficientes para garantir a liquidação da operação, uma assembleia geral será convocada pelo agente fiduciário, de forma que os investidores decidam entre alterar as regras de administração ou liquidar o patrimônio

\footnotetext{
${ }^{37}$ Nos termos do artigo $9^{\circ}$ da Lei ${ }^{\circ} 9.514 / 1997$, o agente fiduciário será instituição financeira ou companhia autorizada para esse fim pelo BACEN.

${ }^{38}$ CAMINHA, Uinie. Securitização, p. 122.
} 
separado. Já em caso de insolvência da companhia securitizadora, o agente fiduciário ficará imediatamente responsável pela custódia e administração do patrimônio separado, devendo também convocar uma assembleia geral para deliberar sobre a forma da administração.

O agente fiduciário atua como o representante dos investidores, cabendo a ele monitorar e fiscalizar a administração do patrimônio separado e proteger os direitos e interesses dos investidores, inclusive através de medidas judiciais e extrajudiciais.

$\mathrm{Na}$ prática se discute se o patrimônio separado seria ou não caracterizado como uma das possíveis garantias a serem prestadas no âmbito da operação de emissão de CRI, tendo em vista que em hipótese de inadimplemento, os recursos oriundos do patrimônio separado serão os primeiros a responder pela dívida. Caso o patrimônio separado seja inexistente ou insuficiente, ai sim se inicia a execução das garantias analisadas nos itens anteriores.

Esse entendimento é reforçado pela redação do $\S 3^{\circ}$, do artigo 11 da Lei $\mathrm{n}^{\circ}$ 9.514/1997, que prevê que "a realização dos direitos dos beneficiários limitar-se-á aos créditos imobiliários integrantes do patrimônio separado, salvo se tiverem sido constituídas garantias adicionais por terceiros".

Outro forte indício está relacionado à estrutura da Lei no 9.514/1997 que segrega, respectivamente, nas Seções VI e VII as disposições sobre o regime fiduciário e as possíveis garantias a serem prestadas em operações de financiamento imobiliário. Nesta lógica, o artigo 17, ao enumerar as garantias não menciona o regime fiduciário e a constituição do patrimônio separado.

Por outro lado, se levarmos em consideração que a constituição do patrimônio separado, apesar de prevista em lei, trata-se de uma faculdade 
concedida à companhia securitizadora, que poderá ou não unilateralmente instituí-lo por declaração no termo de securitização, podemos chegar à conclusão de se tratar de mais uma proteção aos investidores adquirentes do CRI.

\subsection{Participantes das Operações}

Além da sociedade originadora, titular do crédito que pretende captar recursos através da sua securitização e da companhia securitizadora, responsável pela emissão dos CRI no mercado de capitais, as operações ainda contam com outros participantes.

\subsubsection{Agente Fiduciário}

Também chamado de Monitorador, Trustee ou Interveniente Fiduciário, o Agente Fiduciário das emissões de CRI tem como papel principal representar e administrar os interesses dos investidores que irão subscrever os CRI.

Nas palavras de Luiz Ferreira Xavier:

As principais funções do agente fiduciário, nas operações de securitização são: (a) fiscalizar a conduta dos administradores; (b) centralizar os recursos necessários a pagamento dos títulos; e (c) praticar atos que visem a possibilitar que os valores mobiliários colocados junto ao público sejam pagos pontualmente. Deve haver total independência entre o agente fiduciário e os administradores da emissora. Mesmo uma participação minoritária na gestão para facilitar a fiscalização pode significar conflito de interesses no desempenho de sua função ${ }^{39}$.

Em outras palavras, podemos dizer que o Agente Fiduciário é alguém responsável pela administração de recursos ou interesses de terceiros, que no caso serão os investidores dos CRI.

\footnotetext{
${ }^{39}$ BOGES, Luiz Ferreira Xavier. Securitização como parte da segregação de risco empresarial, $\mathrm{p}$. 5 .
} 
Sua presença não é obrigatória, salvo nas operações em que a securitizadora instituir regime fiduciário sobre os créditos imobiliários objetos da emissão ${ }^{40}$.

Veja-se também o diz Melhim Chalhub a respeito do Agente Fiduciário:

A despeito de a lei atribuir, em condições normais, a administração do patrimônio separado à própria securitizadora, ressalva-se que, em hipóteses como má gestão e outras que possam prejudicas os subscritores dos títulos, ela poderá ser afastada da administração, passando o patrimônio de afetação a ser administrado por um agente fiduciário, ao qual a lei confere legitimidade para praticar todos os atos de administração necessários ao resgate dos títulos, podendo o agente fiduciário promover a cobrança e o recebimento dos créditos afetados e, até mesmo, liquidar o patrimônio de afetação, destinando o produto da liquidação ao pagamento das suas próprias obrigações ${ }^{41}$.

A função de Agente Fiduciário encontra fundamento legal nos artigos 66 e seguintes, da Lei nº 6.404/1976, bem como na Instrução CVM n $28 / 1983$, ambas aplicáveis ao agente fiduciário de CRI, por força do $\S 2^{\circ}$, do artigo 13, da Lei $n^{\circ} 9.514 / 1997^{42}$ e do artigo 13 , da Instrução CVM no $414 / 2004^{43}$.

Além de trazer maior segurança jurídica, o Agente Fiduciário também confere aos investidores do CRI uma garantia a mais, tendo em vista que, na qualidade de representante dos investidores, é responsável não só por controlar o cumprimento das obrigações assumidas pela sociedade originadora, mas também por monitorar a existência das demais garantias prestadas, podendo, para tanto, (i) declarar antecipadamente vencidos os CRI e cobrar o seu principal e acessórios; (ii) executar garantias reais, receber o produto da cobrança e aplicá-lo no pagamento dos investidores; (iii) requerer a falência da emissora, se não existirem garantias reais; (iv)

\footnotetext{
${ }^{40}$ Art. $9^{\circ}$ A companhia securitizadora poderá instituir regime fiduciário sobre créditos imobiliários, a fim de lastrear a emissão de Certificados de Recebíveis Imobiliários, sendo agente fiduciário uma instituição financeira ou companhia autorizada para esse fim pelo BACEN e beneficiários os adquirentes dos títulos lastreados nos recebíveis objeto desse regime.

${ }^{41}$ CHALHUB, Melhim Namem. Negócio Fiduciário, p. 380.

${ }^{42} \S 2^{\circ}$ Aplicam-se ao agente fiduciário os mesmos requisitos e incompatibilidades impostos pelo art. 66 da Lei $n^{\circ}$ 6.404, de 15 de dezembro de 1976.

43 Art. 13. Aplicam-se ao agente fiduciário de CRI os direitos, as obrigações e os deveres estabelecidos pela Lei n 9.514, de 1997 e pelas regras que dispõem acerca do exercício da função de agente fiduciário dos debenturistas.
} 
representar os investidores em processos de falência, concordata, intervenção ou liquidação extrajudicial da emissora; e (v) tomar qualquer providência para que os investidores realizem os seus créditos.

\subsubsection{Coordenador Líder ou Underwriter}

Para que uma companhia possa ter acesso ao financiamento através da emissão de títulos e valores mobiliários no mercado de capitais, é necessária a realização de uma oferta pública de distribuição.

No entanto, a Lei $\mathrm{n}^{\circ}$ 6.385, de 07 de dezembro de 1976, a Instrução CVM n 400, de 29 de dezembro de 2003 e a Instrução CVM n 476, de 16 de janeiro de 2009, para fins de proteção dos investidores, determinam que as distribuições públicas devem ser intermediadas por instituições integrantes do sistema de distribuição de valores mobiliários. O coordenador líder ou underwriter de uma operação é a instituição financeira que exerce a função de intermediário da oferta pública distribuição.

\section{Segundo Nelson Eizirik:}

A função econômica fundamental do underwriter é a de servir como um elo de aproximação entre a empresa que emite publicamente os títulos e os investidores, prestando assessoria à companhia emissora em todas as etapas do lançamento ao público de seus valores mobiliários ${ }^{44}$.

A presença desse participante é extremamente importante e relevante por dois motivos: primeiramente, porque para se recorrer diretamente à poupança popular é necessário possuir conhecimento profissional e experiência, características geralmente não presentes nas companhias. Além disso, contratando o intermediário, se busca evitar o risco de espera, o risco do preço e o risco da distribuição, todos inerentes à oferta pública ${ }^{45}$.

\footnotetext{
${ }^{44}$ EIZIRIK, Nelson et. al.. Mercado de Capitais: Regime Jurídico. $3^{\mathrm{a}}$ ed.. Rio de Janeiro: Renovar, 2011, p. 181.

${ }^{45}$ Ibid. p. 179 e 180.
} 
O risco de espera, integralmente assumido pela companhia, está vinculado à possibilidade de alterações nas condições no mercado dentro do tempo transcorrido entre a decisão da companhia de se financiar através da ofertar pública e o momento em que os títulos são efetivamente colocados no mercado.

O risco do preço está atrelado ao equilíbrio entre quanto a companhia pretende captar com a colocação dos títulos e quanto os investidores estão dispostos a pagar pelos mesmos, tendo em vista que a companhia buscará obter o maior preço possível e os investidores o menor possível.

Por fim, o risco da distribuição significa o risco de não subscrição da totalidade dos títulos ofertados no mercado.

Podemos dizer que as instituições financeiras por possuírem maior credibilidade junto aos investidores, têm maior facilidade na colocação de valores mobiliários no mercado. Por isso, muitas vezes, os underwriters acabam assumindo o risco do preço e o risco da distribuição no âmbito dos contratos de distribuição.

Os contratos de distribuição são celebrados entre a companhia emissora e o coordenador líder e preveem não só a forma de remuneração do intermediário, mas também a sua modalidade visto que na prática algumas contratações "se distinguem em função da natureza das atribuições e responsabilidades assumidas pela instituição intermediária (...)" ${ }^{46}$.

Na colocação firme o coordenador líder se compromete a subscrever a totalidade dos títulos para posterior colocação no mercado. Assume, portanto, integralmente o risco da distribuição tendo em vista que caso não haja absorção pelos investidores da totalidade dos títulos, o coordenador não poderá devolvê-los à companhia, pois ao subscrever os valores mobiliários passou a ser titular dos mesmos. "Assim, o underwriter

\footnotetext{
${ }^{46}$ Ibid. p. 182.
} 
subscreve a emissão, pagando de imediato à companhia a importância respectiva e depois passa a colocar os valores mobiliários subscritos junto ao público" ${ }^{47}$.

Por outro lado, na colocação de melhores esforços não existe garantia de subscrição por parte do coordenador líder, ficando este apenas comprometido a realizar seus melhores esforços para colocar os títulos junto aos investidores. Nesse caso, o risco do insucesso da distribuição é assumido integralmente pela companhia emissora.

Por fim, na colocação residual visualizamos uma interseção entre as modalidades de colocação firme e de melhores esforços. Isso porque inicialmente o coordenador líder realiza a colocação dos valores mobiliários na modalidade de melhores esforços e, posteriormente ao período de distribuição, caso existam títulos não subscritos, ele se compromete a adquirir as sobras.

Compete ao coordenador líder, dentre outras obrigações previstas nas Instruções CVM $n^{\circ} \quad 400 / 2003$ e $n^{\circ}$ 476/2009, agir cautelosa e diligentemente, respondendo pela falta de diligência ou omissão, para assegurar que as informações prestadas pela companhia emissora são verdadeiras, consistentes, corretas e suficientes, permitindo aos investidores uma tomada de decisão fundamentada a respeito da oferta.

Por fim, é importante destacar que o artigo $9^{\circ}$ da Instrução CVM n ${ }^{\circ}$ 414, de 30 de dezembro de 2004, normativo dedicado à regulamentação das companhias securitizadoras de crédito imobiliário e das emissões de CRI, prevê uma importante exceção à regra, na medida em que dispensa a participação do coordenador líder nas emissões que envolvam captação não superior a $\mathrm{R} \$ 30.000 .000,00$.

Ibid. p. 183. 
O racional utilizado pelo legislador ao prever essa regra está atrelado ao fato de se entender que uma emissão em montante inferir a $\mathrm{R} \$$ 30.000.000,00 não expõe os investidores a altos riscos, sendo possível um contato direto entre a companhia emissora e o público investidor.

\subsubsection{Agências de Rating}

As agências de rating são empresas especializadas em realizar classificação de risco de crédito e fazem isso através da emissão de relatórios de classificação, baseando-se, para tanto, no grau de risco de não pagamento dos créditos dentro do prazo fixado na operação.

Recentemente a Comissão de Valores Mobiliários editou a Instrução CVM n ${ }^{\circ}$ 521, de 25 de abril de 2012, para regular a atividade de classificação de risco no âmbito do mercado de valores mobiliários. Nos termos do artigo $1^{\circ}$, é considerada agência de classificação de risco a "pessoa jurídica registrada ou reconhecida pela CVM que exerce profissionalmente a atividade de classificação de risco de crédito no âmbito do mercado de valores mobiliários" e classificação de risco de crédito a "atividade de opinar sobre a qualidade de crédito de um emissor de títulos de participação ou de dívida, de uma operação estruturada, ou qualquer ativo financeiro emitido no mercado de valores mobiliários".

No âmbito de uma emissão de certificado de recebível imobiliário, a securitizadora, emissora da operação, contrata uma agência de rating que ficará responsável por avaliar a estrutura da operação de emissão do CRI, a validade e existência dos créditos utilizados como lastro da emissão, a qualidade das garantias prestadas e, ao final, emitir um rating da operação. 


\subsection{Tipos de Oferta Pública de Distribuição}

Nos termos do artigo 19 da Lei $\mathrm{n}^{\circ}$ 6.385/1976 "nenhuma emissão pública de valores mobiliários será distribuída no mercado sem prévio registro na Comissão".

No âmbito desta sua competência, a CVM editou a Instrução CVM n 400/2003, em geral, aplicável a todas as ofertas públicas de valores mobiliários e assim como a intermediação por instituição financeira, a exigência de registro prévio da distribuição pública na CVM está vinculada à proteção dos investidores. Veja-se, a redação do artigo $1^{\circ}$ da Instrução CVM n 400/2003:

Esta instrução regula as ofertas públicas de distribuição de valores mobiliários, nos mercados primário ou secundário e tem por fim assegurar a proteção dos interesses do público investidor e do mercado em geral, através do tratamento equitativo aos ofertados e de requisito de ampla, transparente e adequada divulgação de informações sobre a oferta, os valores mobiliários ofertados, a companhia emissora, o ofertante e demais pessoas envolvidas.

No âmbito da securitização imobiliária, foi editada a Instrução CVM $n^{\circ} 414 / 2004$, para regular o registro das companhias securitizadoras de créditos imobiliários e as ofertas públicas de distribuição de CRI na CVM.

Nos termos do artigo $9^{\circ}$ da Instrução CVM $n^{\circ}$ 414/2004, uma emissão de certificado de recebível imobiliário, em regra, está sujeita às previsões da Instrução CVM n 400/2003, devendo ser submetida ao registro prévio na CVM (artigo $\left.2^{\circ}\right)^{48}$ e contar com a intermediação do coordenador líder $\left(\$ 2^{\circ} \text { do artigo } 3^{\circ}\right)^{49}$.

No entanto, além da exceção referente à participação do coordenador líder prevista pelo artigo $9^{\circ}$ (tratada no subitem 4.7.2), as emissões de CRI e

\footnotetext{
${ }^{48}$ Art. $2^{\circ}$. Toda oferta pública de distribuição de valores mobiliários nos mercados primário e secundário, no território brasileiro, dirigida a pessoas naturais, jurídicas, fundos ou universalidade de direitos, residentes, domiciliados ou constituídos no Brasil, deverá ser submetida previamente a registro na Comissão de Valores Mobiliários - CVM, nos termos desta Instrução.

${ }^{49} \S 2^{\circ}$. A distribuição pública de valores mobiliários somente pode ser efetuada com intermediação das instituições integrantes do sistema de distribuição de valores mobiliários ("Instituições Intermediárias"), ressalvadas as hipóteses do sistema de dispensa específica deste requisito, concedidas nos termos do art. $4^{\circ}$.
} 
de alguns outros valores mobiliários passaram a contar com a possibilidade de dispensa de registro prévio na CVM em razão da edição da Instrução $\mathrm{CVM} \mathrm{n}^{\circ}$ 476, de 16 de janeiro de 2009, que dispõe sobre a modalidade de distribuição com esforços restritos.

Esse tipo de distribuição se caracteriza pela (i) restrição da oferta, que só poderá ser feita a, no máximo, 50 investidores qualificados ${ }^{50}$; e (ii) restrição da subscrição ou aquisição dos títulos ofertados, que só poderá ser feita por, no máximo, 20 investidores.

Além disso, como mencionado, nos termos do artigo $6^{\circ}$ da referida instrução "as ofertas públicas distribuídas com esforços restritos estão automaticamente dispensadas do registro de distribuição de que trata o caput do art. 19 da Lei $n^{\circ}$ 6.385, de 1976”. Porém, é importante destacar que isso não implica na dispensa de intermediação da distribuição. Pelo contrário, o artigo $2^{\circ}$ da Instrução CVM no 476/2009 é expresso ao dispor que as ofertas públicas com esforços restritos deverão ser intermediadas por integrante do sistema de distribuição de valores mobiliários.

Essa exigência se mantém e se reforça tendo em vista que, não havendo registro e fiscalização por parte da CVM, o coordenador líder

\footnotetext{
50 Nos termos do artigo $4^{\circ}$ da Instrução CVM n $n^{\circ} 476 / 2009$, "consideram-se investidores qualificados, os referidos do art. 109 da Instrução CVM n ${ }^{\circ}$ 409, de 18 de agosto de 2004, observado que: I - todos os fundos de investimento serão considerados qualificados, mesmo que se destinem a investidores não qualificados; e II - as pessoas naturais e jurídicas mencionadas no inciso IV do art. 109 da Instrução CVM n ${ }^{\mathbf{0}}$ 409, de 2004, deverão subscrever ou adquirir, no âmbito da oferta, valores mobiliários no montante mínimo de R\$1.000.000,00 (um milhão de reais)".

Dispõe o artigo 109 da Instrução CVM no 409/2004:

Art. 109. Para efeito do disposto no artigo anterior, são considerados investidores qualificados:

I - instituições financeiras;

II - companhias seguradoras e sociedades de capitalização;

III - entidades abertas e fechadas de previdência complementar;

IV - pessoas físicas ou jurídicas que possuam investimentos financeiros em valor superior a $\mathrm{R} \$$ 300.000,00 (trezentos mil reais) e que, adicionalmente, atestem por escrito sua condição de investidor qualificado mediante termo próprio, de acordo com o Anexo I; $\mathrm{V}$ - fundos de investimento destinados exclusivamente a investidores qualificados;

VI - administradores de carteira e consultores de valores mobiliários autorizados pela CVM, em relação a seus recursos próprios;

VII - regimes próprios de previdência social instituídos pela União, pelos Estados, pelo Distrito Federal ou por Municípios.
} 
assume as responsabilidades referentes ao acesso dos investidores às informações da emissão. 


\section{Conclusão}

Conforme abordado, o mecanismo financeiro da securitização surgiu como uma solução às novas demandas dos mercados financeiro e de capitais. A utilização deste instrumento se justifica na medida em que representa para as sociedades uma alternativa aos meios tradicionais de financiamento, tratando-se de um mecanismo de obtenção de recursos a um custo menor, sem sacrificar sua saúde financeira.

Como visto, pode-se conceituar a securitização como sendo a operação na qual um direito de crédito é transformado em um título ou valor mobiliário. Sendo assim, o requisito primordial para a estruturação de uma securitização é a existência do crédito e a primeira fase da operação, a sua segregação.

A transferência dos créditos para uma SPE permitirá que esta sociedade, especialmente constituída para este fim, na qualidade de titular dos créditos, emita valores mobiliários no mercado com o intuito de captar recursos, que serão destinados ao pagamento pela aquisição dos créditos, anteriormente de titularidade da sociedade originadora.

Dentre os benefícios aproveitados pela sociedade originadora nesta estrutura, foram destacados os seguintes: (i) a antecipação de receitas sem prejudicar sua saúde financeira; (ii) a diluição do risco da sua carteira de recebíveis; e (iii) captação de recursos por um custo muito inferior quando comparado aos meios tradicionais de financiamento. Para o investidor, a principal vantagem da securitização é a opção por um investimento de baixo risco, característica decorrente da segregação do risco, tendo em vista que os riscos envolvidos na atividade econômica da sociedade originadora estão totalmente desvinculados dos títulos e valores mobiliários negociados no mercado. 
No que diz respeito ao arcabouço legal atualmente existente no Brasil, viu-se que a questão regulatória gera algumas divergências quanto à necessidade ou não da edição de legislação própria e específica a ser aplicada às securitizações em geral. Este debate ganha espaço tendo em vista que as normas relacionadas à securitização acabaram se desenvolvendo de acordo com o ativo sobre o qual a estrutura é lastreada.

Finalmente, buscou-se analisar quais as finalidades da utilização das securitizações no âmbito imobiliário, para então, detalhar as etapas envolvidas em uma operação de emissão de certificados de recebíveis imobiliários, destacando cada uma das fases (constituição do crédito, segregação do risco, emissão do título) e analisando não só as principais garantias prestadas no âmbito das operações, como também os participantes da estrutura.

No âmbito prático, a securitização está em ritmo crescente. De acordo com as últimas informações divulgadas pela CVM, presentes no Relatório Anual de 2011, as distribuições públicas de CRI, entre os anos de 2010 e 2011, passaram de $R \$ 7,7$ milhões para $R \$ 13,5$ milhões, o que representa um aumento de $75 \%$. Portanto, não restam dúvidas quanto à consolidação da securitização como mecanismo de financiamento e quanto à sua grande aceitação pelo mercado. Será apenas com as experiências práticas que o mercado poderá suscitar e solucionar novos questionamentos e amadurecer a aplicação deste instrumento. 


\section{Referências Bibliográficas}

BATISTA, Felipe Mendes. Instrumentos de Securitização - Uma Análise Comparativa com os Tipos de Mecanismos de Captação de Recursos. (Disponível em: http://www.bi-invest.com.br/pdf/projeto-artigosecuritizacao-fia.pdf) Acesso em: 05.05.2013.

BOGES, Luiz Ferreira Xavier. Securitização como parte da segregação de risco empresarial. Revista de Direito Bancário e do Mercado de Capitais. Vol. 10. Outubro de 2000.

CAMARGO, Cristiane Bueno; SISTI, Carlos Eduardo Poli; FERREIRA, Rogéria Cristina. Built to Suit, Direito Real de Superfície e Sale and Leaseback, uma Análise Comparativa. (Disponível em: http://www.lares.org.br/2010/anais2010/images/461-542-1-SP.pdf) Acesso em: 05.05.2013.

CAMINHA, Uinie. Securitização. $2^{a}$ ed.. São Paulo: Saraiva, 2007. 205 p.

CHALHUB, Melhim Namem. A Cessão Fiduciária e a Recuperação Judicial. Publicado em 24.07.2009. Valor Econômico (Disponível em: http://www.melhimchalhub.com.br/noticia/detalhe/7/a-cessao-fiduciaria-ea-recuperacao-judicial-) Acesso em: 03.05.2013.

- Alienação Fiduciária, Incorporação Imobiliária e Mercado de Capitais. Estudos e Pareceres. Rio de Janeiro: Renovar, 2012. 577 p.

. Da Incorporação Imobiliária. $3^{\text {a }}$ ed.. Rio de Janeiro: Renovar, 2012. $543 \mathrm{p}$. . Negócio Fiduciário. $4^{\mathrm{a}}$ ed.. Rio de Janeiro: Renovar, 2009. 455 p.

CUNHA, Leandro Cunha. Características Gerais dos Títulos de Crédito, com foco no Mercado Financeiro. (Disponível em: http://www.bi- 
invest.com.br/pdf/principais-caracteristicas-dos-titulos-de-credito.pdf)

Acesso em: 05.05.2013.

DA SILVA, Daniel José Cardoso; MACÊDO, João Marcelo Alves; VERAS, José Airton Galdino; VASCONCELOS, Marco Tullio de Castro. Securitização: Uma Alternativa Viável para a Redução das Despesas Financeiras das Empresas Brasileiras? Qualit@as Revista Eletrônica ISSN 1677 4280. Vol. 9. $\mathrm{n}^{\mathrm{o}}$ 2. 2010. (Disponível em: http://revista.uepb.edu.br/index.php/qualitas/article/viewFile/836/475)

Acesso em: 05.05.2013.

EIZIRIK, Nelson et. al.. Mercado de Capitais: Regime Jurídico. $3^{\text {a }}$ ed.. Rio de Janeiro: Renovar, 2011. 660 p.

GAGGINI, Fernando Schwarz. Securitização de Recebiveis. São Paulo: Livraria e Editora Universitária de Direito, 2003. 95 p.

GONÇALVES, Carlos Roberto. Direito Civil Brasileiro. Direito das Coisas. Vol. 5. 5ª ed.. São Paulo: Saraiva, 2010. 655 p.

ROSA JUNIOR, Luiz Emygdio Franco da. Títulos de Crédito. $7^{\mathrm{a}}$ ed. Revista e atualizada. Rio de Janeiro: Renovar, 2011. 788 p.

TEPEDINO, Gustavo; BARBOZA, Heloisa Helena; BODIN DE MORAES, Maria Celina. Código Civil interpretado conforme a Constituição da República. Vol. II. Rio de Janeiro: Renovar, 2006. 909 p.

VALENÇA, Marcelo José Lomba. Built to Suit - Operação de Crédito Imobiliária Estruturada. Revista de Direito Bancário e do Mercado de Capitais. Vol. 27. Janeiro de 2005.

CVM, PAS RJ 2002/3032, Rel. Luiz Antônio de Sampaio Campos, 13 mai. 2003.

CVM, PAS RJ 2004/6913, Rel. Marcelo Fernandez Trindade, 04 out. 2005. 
CVM, PAS RJ 2007/547, Rel. Marcelo Fernandez Trindade, 10 jul. 2007.

CVM, PAS RJ 2001/1981, Rel. Wladimir Castelo Branco Castro, 14 mai. 2002 . 